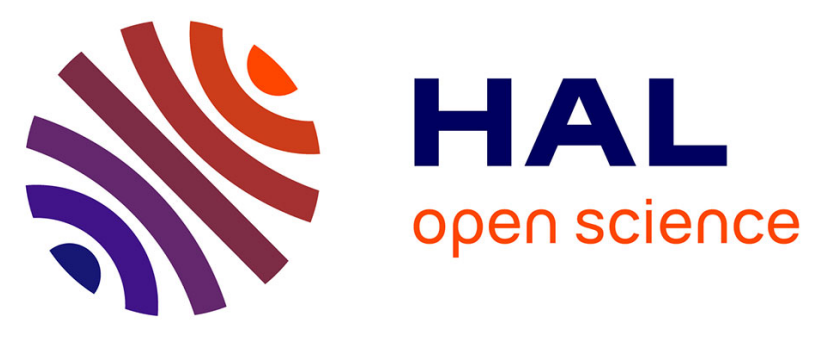

\title{
Enhanced clinical phenotyping by mechanistic bioprofiling in heart failure with preserved ejection fraction: insights from the MEDIA-DHF study (The Metabolic Road to Diastolic Heart Failure)
}

Susan Stienen, Joao Pedro Ferreira, Masatake Kobayashi, Gregoire Preud'Homme, Daniela Dobre, Jean-Loup Machu, Kévin Duarte, Emmanuel Bresso, Marie-Dominique Devignes, Natalia López Andrés, et al.

\section{- To cite this version:}

Susan Stienen, Joao Pedro Ferreira, Masatake Kobayashi, Gregoire Preud'Homme, Daniela Dobre, et al.. Enhanced clinical phenotyping by mechanistic bioprofiling in heart failure with preserved ejection fraction: insights from the MEDIA-DHF study (The Metabolic Road to Diastolic Heart Failure). Biomarkers, 2020, 25 (2), pp.201-211. 10.1080/1354750X.2020.1727015 . hal-02732968

\section{HAL Id: hal-02732968 \\ https://hal.univ-lorraine.fr/hal-02732968}

Submitted on 2 Jun 2020

HAL is a multi-disciplinary open access archive for the deposit and dissemination of scientific research documents, whether they are published or not. The documents may come from teaching and research institutions in France or abroad, or from public or private research centers.
L'archive ouverte pluridisciplinaire HAL, est destinée au dépôt et à la diffusion de documents scientifiques de niveau recherche, publiés ou non, émanant des établissements d'enseignement et de recherche français ou étrangers, des laboratoires publics ou privés. 
Enhanced Clinical Phenotyping by Mechanistic Bioprofiling in Heart Failure with Preserved Ejection Fraction: Insights from the MEDIA-DHF study (The Metabolic

\section{Road to Diastolic Heart Failure)}

Susan Stienen, $\mathrm{MD}, \mathrm{PhD}^{1}$; João Pedro Ferreira, $\mathrm{MD}, \mathrm{PhD}^{1,2}$; Masatake Kobayashi, $\mathrm{MD}^{1}$; Gregoire Preud'homme MSc ${ }^{1}$; Daniela Dobre ${ }^{1,3}$, Jean-Loup Machu, MSc ${ }^{1}$; Kevin Duarte $\mathrm{PhD}^{1}$; Emmanuel Bresso, $\mathrm{PhD}^{4}$; Marie-Dominique Devignes, $\mathrm{PhD}^{4}$; Natalia López Andrés, $\mathrm{PhD}^{5}$; Nicolas Girerd, MD, $\mathrm{PhD}^{1}$; Svend Aakhus ${ }^{6,7}$; Giuseppe Ambrosio ${ }^{8}$; Hans-Peter Brunner-La Rocca, MD, PhD ${ }^{9}$; Ricardo Fontes-Carvalho ${ }^{10}$; Alan G. Fraser ${ }^{11}$; Loek van Heerebeek, MD, PhD ${ }^{12}$; Stephane Heymans ${ }^{13,14,15}$ Gilles de Keulenaer ${ }^{16}$; Paolo Marino ${ }^{17}$; Kenneth McDonald ${ }^{18}$; Alexandre Mebazaa ${ }^{19}$; Zoltàn Papp, $\mathrm{PhD}^{20}$; Riccardo Raddino ${ }^{21}$; Carsten Tschöpe ${ }^{22}$; Walter J. Paulus, MD, $\mathrm{PhD}^{23}$; Faiez Zannad, MD, $\mathrm{PhD}^{1 ¥}$; Patrick Rossignol, $\mathrm{MD}, \mathrm{PhD}^{1} ¥$

\footnotetext{
${ }^{1}$ Université de Lorraine, INSERM, Centre d'Investigation Clinique et Plurithématique 1433, INSERM U1116, CHRU de Nancy, F-CRIN INI-CRCT (Cardiovascular and Renal Clinical Trialists), Nancy, France;

${ }^{2}$ Department of Physiology and Cardiothoracic Surgery, Cardiovascular Research and Development Unit, Faculty of Medicine, University of Porto, Porto, Portugal;

${ }^{3}$ Clinical research and Investigation Unit, Psychotherapeutic Center of Nancy, Laxou, France

${ }^{4}$ LORIA (CNRS, Inria NGE, Université de Lorraine), Campus Scientifique, F-54506, Vandœuvre-lès-Nancy, France;

${ }^{5}$ Navarrabiomed, Complejo Hospitalario de Navarra (CHN), Universidad Pública de Navarra (UPNA), IdiSNA. Pamplona. Spain ;

${ }^{6}$ Oslo University Hospital, Oslo, Norway

${ }^{7}$ ISB, Norwegian University of Science and Technology, Trondheim, Norway;

${ }^{8}$ Division of Cardiology, University of Perugia School of Medicine, Perugia, Italy;

${ }^{9}$ Department of Cardiology, Maastricht University Medical Center, Maastricht, the Netherlands;

${ }^{10}$ Department of Surgery and Physiology, Cardiovascular Research Unit (UnIC), Faculty of Medicine, University of Porto, Porto, Portugal;

${ }^{11}$ Wales Heart Research Institute, Cardiff University, Cardiff, United Kingdom;

${ }^{12}$ Department of Cardiology, Onze Lieve Vrouwe Gasthuis, Amsterdam, the Netherlands;

${ }^{13}$ Department of Cardiology, CARIM School for Cardiovascular Diseases Faculty of Health, Medicine and Life Sciences, Maastricht University, The Netherlands.

${ }^{14}$ Department of Cardiovascular Sciences, Centre for Molecular and Vascular Biology, KU Leuven, Belgium.

${ }^{15}$ William Harvey Research Institute, Barts Heart Centre, Queen Mary University of London,Charterhouse Square, London EC1M 6BQ.

${ }^{16}$ Laboratory of Physiopharmacology, Antwerp University, and ZNA Hartcentrum, Antwerp, Belgium;

${ }^{17}$ Clinical Cardiology, Università del Piemonte Orientale, Department of Translational Medicine, Azienda Ospedaliero

Universitaria "Maggiore della Carità", Novara, Italy;

${ }^{18}$ St Michael's Hospital Dun Laoghaire Co. Dublin, Dublin, Ireland;
} 
${ }^{19}$ Department of Anaesthesiology and Critical Care Medicine, Saint Louis and Lariboisière University Hospitals and INSERM UMR-S 942, Paris, France;

${ }^{20}$ Division of Clinical Physiology, Department of Cardiology, Faculty of Medicine, University of Debrecen, Debrecen, Hungary ;

${ }^{21}$ Department of Cardiology, Spedali Civili di Brescia, Brescia, Italy;

${ }^{22}$ Department of Cardiology, Campus Virchow-Klinikum, Charite Universitaetsmedizin Berlin, Berlin Institute of Health Center for Regenerative Therapies (BIH-BCRT), and the German Center for Cardiovascular Research (DZHK ; Berlin partner site), Berlin, Germany;

${ }^{23}$ Amsterdam Cardiovascular Sciences, Amsterdam University Medical Centers, Amsterdam, the Netherlands

$¥$ both authors contributed equally as last author

Address for correspondence:

\section{Susan Stienen}

Centre d'Investigations Cliniques-INSERM CHU de Nancy,

Institut Lorrain du Cœur et des Vaisseaux Louis Mathieu,

4 Rue du Morvan, 54500 Vandoeuvre lès Nancy, France.

E-mail: s.stienen@amc.uva.nl 


\begin{abstract}
Background

Heart failure with preserved ejection fraction (HFpEF) is a heterogeneous syndrome for which clear evidence of effective therapies is lacking. Understanding which factors determine this heterogeneity may be helped by better phenotyping. An unsupervised statistical approach applied to a large set of biomarkers may identify distinct HFpEF phenotypes.

Methods

Relevant proteomic biomarkers were analyzed in $392 \mathrm{HFpEF}$ patients included in Metabolic Road to Diastolic HF(MEDIA-DHF). We performed an unsupervised cluster analysis to define distinct phenotypes. Cluster characteristics were explored with logistic regression. The association between clusters and 1-year cardiovascular (CV) death and/or CV hospitalization was studied using Cox regression.

Results

Based on 415 biomarkers we identified 2 distinct clusters. Clinical variables associated with cluster 2 were diabetes, impaired renal function, loop diuretics and/or betablockers.

Additionally, 17 biomarkers were higher expressed in cluster 2 vs. 1. Patients in cluster 2 vs. those in 1 experienced higher rates of CV death/CV hospitalization (adj.HR 1.93,95\%CI 1.12$3.32, \mathrm{p}=0.017$ ). Complex-network analyses linked these biomarkers to immune system activation, signal transduction cascades, cell interactions, and metabolism.

Conclusion

Unsupervised machine-learning algorithms applied to a wide range of biomarkers identified 2 HFpEF clusters with different CV phenotypes and outcomes. The identified pathways may provide a basis for future research.
\end{abstract}

Keywords:

HFPEF, machine learning, biomarkers, cluster analysis, phenotype, complex-network analysis 


\section{Introduction}

Heart failure with preserved ejection fraction (HFpEF) is a clinical syndrome with multiple causes, and little evidence for effective therapies (Ponikowski et al., 2016). The increasing prevalence of $\mathrm{HFpEF}$ and its poor prognosis both make it important to understand the factors contributing to the heterogeneity of the syndrome and its underlying mechanisms (Tsao et al., 2018).

Several studies have sought to identify distinct HFpEF phenotypes based on clinical, echocardiographic and hemodynamic characteristics (Kao et al., 2015; Sanchez-Martinez et al., 2018; Shah et al., 2015; Tabassian et al., 2018). Additionally, biomarkers have also been studied in an attempt to identify HFpEF subgroups with different characteristics and prognosis(Hage et al., 2017; Sanders-van Wijk et al., 2015; Santhanakrishnan et al., 2012; Tromp et al., 2017; Tromp et al., 2018). In these studies, only a limited number of biomarkers were assessed (up to a maximum of 92 biomarkers). Whether a wider biomarker panel may provide further information on the pathophysiology of HFpEF is yet to be determined.

In this study, we performed unsupervised machine-learning algorithms using 415 proteomic biomarkers to identify HFpEF potential mechanistic phenotypes in a prospective observational cohort of HFpEF patients (The Metabolic Road to Diastolic Heart Failure study (MEDIA-DHF); NCT02446327). 


\section{Methods}

\section{Study population}

Between 2012 and 2014, 626 patients were enrolled in MEDIA-DHF ((NCT02446327) which was a multicenter, multinational, observational study in 10 centers (listed in Supplemental table 1). After standardized echocardiography (Supplemental data) and/or local natriuretic peptide measurements, eligible patients were included when they had a diagnosis of left ventricular diastolic dysfunction following 2007 ESC consensus recommendations (Paulus et al., 2007). Patients included in MEDIA-DHF presented as: 1) acute decompensated HF patients, or 2) patients recently discharged after admission for an acute HF episode $(<60$ days), or 3) ambulatory chronic disease patients. At inclusion in the study, data on demographics, clinical parameters, laboratory values (including biomarker measurements), electrocardiography and echocardiography were obtained. Follow-up took place at 3, 6 and 12 months after inclusion in the study.

For this substudy, only patients with available biomarkers were included ( $N=392$; see also the flowchart in Supplemental figure 1). There were no biomarker measurements in acute decompensated HF patients. The study protocol complied with the Declaration of Helsinki and was approved by the respective Ethics Committees of the participating institutions. All patients provided written informed consent. (ClinicalTrials.gov Identifier: NCT02446327)

\section{Biomarker measurements}

Plasma samples taken at inclusion in the study were analyzed for protein biomarkers (including natriuretic peptides) using 5 different Olink Proseek Multiplex panels: cardiovascular disease (CVD) II, CVD III, Inflammation, Cardiometabolic and Organ damage (Olink Proteomics, Uppsala, Sweden). The characteristics of the biomarkers within the different Olink panels are described in Supplemental table 2 (and www.olink.com). For this 
assay, a proximity extension assay (PEA) technology is used where 92 oligonucleotidelabelled antibody probe pairs per panel may bind to their respective targets in $1 \mu \mathrm{L}$ plasma sample (Lundberg, Eriksson, Tran, Assarsson, \& Fredriksson, 2011). When bound, they give rise to new DNA amplicons with each ID barcoding their respective antigens. Quantification of the amplicons is subsequently performed using a Fluidigm BioMark HD real-time PCR platform. The PCR platform provides log2-normalized protein expression (NPX) data and an increase of 1 NPX means a doubling in concentration of the specific biomarker. Forty-five proteins that were below the lower limit of detection (LOD) in more than $50 \%$ of the patients, were excluded from further analyses ( $\mathrm{N}=45$ biomarkers excluded). For the proteins below the LOD in less than $50 \%$ of patients, the LOD value was imputed. A total of 415 protein biomarkers were studied.

\section{Cluster analysis}

Pearson correlations were assessed between 415 biomarkers. When two biomarkers were highly correlated $(>0.8)$, the biomarker with the largest mean absolute correlation was excluded. Hence, 66 biomarkers were excluded from further analyses. The optimal number of clusters was determined using the NbClust package in $\mathrm{R}$ (distance=euclidean, min.nc=2, max.nc=15, method=kmeans, index=alllong). Next, k-means cluster analysis (nstart=1000) was performed with data of 349 biomarkers to partition the patients into separate clusters. There were no missing values for these biomarkers. Cluster stability was verified using Clusterboot $(\mathrm{B}=100$, clustermethod=kmeansCBI). Jaccard similarities values were highly stable (cluster $1=0.91$; cluster $2=0.93$ ). The cluster analysis resulted in two different patient clusters (clusters 1 and 2).

\section{Network analyses}


The FHF-GKB (Fight Heart Failure - Graph Knowledge Box) resource, representing most available public knowledge about human protein-disease, protein-protein and protein-pathway relationships is a customized upgraded version of the EdgeBox provided by the EdgeLeap company (available from: https://www.edgeleap.com/edgebox/). FHF-GKB data is extracted from public data sources resulting in 20,386 protein nodes imported from Uniprot("UniProt: the universal protein knowledgebase," 2017), including all biomarkers involved in this study, 28,176 disease nodes from Disease Ontology(Kibbe et al., 2015) and DisGenet(Pinero et al., 2017) and 2,222 pathway nodes from Reactome (v65)(Fabregat et al., 2018). Protein - protein relationships were retrieved from STRING (v10.5) (Szklarczyk et al., 2015), Reactome or WikiPathways(Slenter et al., 2018), Mentha(Calderone, Castagnoli, \& Cesareni, 2013), or BioGrid(Chatr-Aryamontri et al., 2017) and protein - pathway relationships from Reactome.

\section{Cardiovascular outcome}

The pre-specified endpoint of MEDIA-DHF was a composite of CV death and/or CV hospitalizations (NCT02446327). Clinical outcomes were ascertained by telephone interview and recorded in the electronic case report form (including date and place). For hospitalizations, the letter of discharge was provided, while the death certificate was provided in instances of mortality. The primary outcome of this specific substudy was cardiovascular hospitalizations or cardiovascular death at 12 months. Endpoints were adjudicated by a committee blinded to the biomarker data.

\section{Statistical analyses}

Baseline clinical, demographic and echocardiographic characteristics across clusters were compared using chi-square, t-test or Mann-Whitney tests, as appropriate. 
To identify clinical variables associated with cluster membership defined by the protein biomarkers, a logistic regression analysis was performed. All variables considered are listed in Supplemental table 3. Missing predictor values with $<20 \%$ of missing values were imputed using linear regression analysis (see Table 1 for the percentage of missing data for each variable). We imputed missing data 10 times, performed the analysis over all the 10 imputations and averaged results using Rubin's rules (Rubin, 2004). Log-linearity of continuous variables was assessed visually by inspecting the shape of the distribution of the beta-estimates vs. the median by quintiles with regard to the outcome of interest (cluster 2). If deemed appropriate based on log-linearity, continuous variables were categorized. Variables with significant $p$-values $(<0.05)$ in univariate analyses were considered in the multivariate model. Age and sex were "forced" in the model. The discrimination of the final multivariate model was assessed by calculating the area under the curve (AUC). Similar beta-estimates of variables in the multivariate model derived from the multiple imputation datasets were obtained when the pooled mean eGFR and E/E' were imputed in the original datasets (in $\mathrm{N}=23$ and $\mathrm{N}=26$ patients respectively; data not shown). Further analyses were therefore performed in the original dataset.

Thereafter, we studied which specific biomarkers were significantly associated with cluster 2 membership on top of the clinical multivariate model accounting for multiple comparisons using a Bonferroni adjusted p-value of $<0.00014$. To identify independent biomarkers, we subsequently excluded those correlated to each other ( $>0.3)$. Also here, from two correlated biomarkers, the biomarker with the largest mean absolute correlation was excluded.

The FHF-GKB complex network was queried in order to explore pathways and proteins that could connect together biomarker (BM) nodes of interest. Queries were expressed according to query patterns defining a path structure between two nodes such as 
BM-BM and BM-pathway-BM, where the BM nodes are taken from a list of interest. The resulting graphs were merged in a figure illustrating all possible paths not longer than two edges, connecting BMs through pathways.

The association between cluster membership and the composite endpoint of CV death and/or CV hospitalizations (primary endpoint of MEDIA-DHF) within 1 year after inclusion in the study was studied using Kaplan-Meier estimates and Cox proportional hazards models. To derive clinical variables for adjustment, we constructed a clinical risk model (considering all aforementioned clinical variables) and used the variables that were significantly associated with the primary outcome in multivariate Cox regression as adjustment variables. Natriuretic peptides were included in the cluster analysis and therefore not included in the prognostic model. All significant clinical variables $(\mathrm{p}<0.05)$ in univariate analysis were considered for the multivariate risk model. Age (per 10 years increase) and sex were "forced" in the model.

Statistical analyses were performed using SPSS 24 (IBM inc., Armonk, New York) and R (The R Foundation for Statistical Computing, Vienna, Austria).

\section{Results}

\section{Cluster characteristics}

The optimal number of clusters within this biomarker substudy of MEDIA-DHF was 2 (Supplemental figure 2). The distribution of demographic, clinical and echocardiographic variables according to the specific clusters is summarized in Table 1. Compared to cluster 1, patients in cluster 2 were older, more often had a recent episode of decompensated HF $(<60$ days), a previous HF hospitalization, atrial fibrillation, diabetes mellitus, peripheral arterial disease, NYHA class III/IV, complaints of fatigue on exertion, anemia, lower diastolic blood pressure, lower cholesterol measures (total cholesterol, LDL and HDL), worse renal function, 
higher E/e', lower TAPSE and higher E/A. In addition, they were more often prescribed betablockers, loop or thiazide diuretics, oral anticoagulants, and insulin.

\section{Clinical determinants of cluster 2 membership}

Crude and adjusted odds ratios for the association between clinical variables and cluster 2 membership are listed in Table 2. There were four variables independently associated with cluster 2 membership: prescription of loop diuretics or betablockers, diabetes mellitus, and lower eGFR (="clinical model").

\section{Association between biomarkers and cluster 2 membership}

For all individual biomarkers, associations with cluster 2 membership were assessed on top of the clinical model. A total of 17 biomarkers were identified (Table 3). These were: angiopoietin-1 receptor (TIE2), ectonucleoside triphosphate diphosphohydrolase 2 (ENTPD2), eotaxin (CCL11), tumor necrosis factor ligand superfamily member 13B (TNFSF13B), platelet-derived growth factor C (PDGFC), L-selectin (SELL), proprotein convertase subtilisin/kexin type 9 (PCSK9), tumor necrosis factor (Ligand) superfamily, member 12 (TWEAK), nitric oxide synthase (NOS3), granulysin (GNLY), E-selectin (SELE), serpin A9 (SERPINA9), azurocidin (AZU1), proto-oncogene tyrosine-protein kinase Src (SRC), adhesion G-protein coupled receptor G1 (ADGRG1), fibroblast growth factor 21 (FGF21) and growth hormone (GH). Addition of these 17 biomarkers to the clinical model significantly improved the multivariate model for the prediction of cluster 2 membership (AUC from 0.81 to 0.96). Distribution of the biomarkers according to the respective clusters is listed in Supplemental table 4.

\section{Network analyses}


Of the 17 cluster-associated protein biomarkers, 15 were linked with each other by known direct interactions or pathway-interactions linked to the immune system, signal transduction/cell interactions and metabolism (Figure 1).

\section{Clinical risk model for cardiovascular outcome}

Crude and adjusted hazard ratios for clinical variables associated with CV death and/or CV hospitalization are listed in Supplemental table 5. These variables were a history of CAD, pulmonary rales, age and sex.

\section{Cluster outcomes}

The composite endpoint of CV death and/or CV hospitalization occurred more often in cluster 2 compared to cluster 1 (resp. $20 \%$ (33/163) versus $12 \%$ (27/229), Log rank test: $p=0.024$; Figure 2). After adjustment for the clinical risk model, patients within cluster 2 had a significantly higher rate of $\mathrm{CV}$ death and/or CV hospitalizations than those in cluster 1 (adjusted hazard ratio $1.93,95 \%$ CI 1.12-3.32, $\mathrm{p}=0.017$ ). Adjusting on additional clinical variables in the model (such as previous HF hospitalization, diabetes mellitus, renal function, systolic blood pressure and different HF medication) did not change the significant association between cluster assignment and outcome (Supplemental table 6).

\section{Discussion}

The performance of unsupervised machine learning using data on $>400$ biomarkers in a large cohort of $392 \mathrm{HFpEF}$, otherwise well-characterized patients, led to the identification of 2 distinct HFpEF clusters. In addition to differences in clinical features and cardiovascular prognosis between clusters, we found 17 biomarkers to be significantly associated with cluster membership. This may indicate differences in pathophysiological mechanisms. 


\section{Differences between clusters: clinical features}

Clinical variables that were significantly associated with cluster 2 membership were the prescription of loop diuretics or betablockers, diabetes mellitus, and lower eGFR. These have previously been associated with poor prognosis in HFpEF patients (Damman et al., 2014; Tribouilloy et al., 2008) and may indicate the presence of a cardiorenal syndrome as recently proposed (Zannad \& Rossignol, 2018).

\section{Differences between clusters: biomarkers and mechanistic significance}

In this study, plasma levels of 17 biomarkers were significantly more elevated in cluster 2 compared to cluster 1 . Network analysis revealed that these biomarkers may be grouped in 3 different mechanistic pathways: the immune system, signal transduction/cell interactions and metabolism. An overview of the biomarkers and their mechanistic significance is given in Table 4.

Other studies with smaller samples and fewer biomarkers found several biomarkers associated with outcome in HFpEF. In a sub study of Karolinska Rennes (KaRen), growth/differentiation factor-15 (GDF-15) was the strongest predictor for poor outcome (Hage et al., 2017), while Tromp et al. investigated 33 biomarkers in a cohort of HF patients and demonstrated that the remodeling marker osteopontin and the angiogenesis marker neuropilin predicted outcome (Tromp et al., 2017). Another study compared profiles of 92 biomarkers between HFrEF, HFmrEF and HFpEF patients and found that central proteins in HFpEF were integrin subunit beta-2 and catenin beta-1 (Tromp et al., 2018). A substudy of the Trial of Intensified versus standard Medical therapy in Elderly patients with Congestive Heart Failure (TIME-CHF) compared 15 biomarker from different pathways between HFrEF and HFpEF patients and found that markers of inflammation (hsCRP and cystatin C), fibrosis 
(ST2) and anemia (hemoglobin) were more prominent in HFpEF than in HFrEF(Sanders-van Wijk et al., 2015). Interestingly, our results are novel since no overlap was present between the biomarkers that we found in our study and the biomarkers in other HFpEF studies(Hage et al., 2017; Santhanakrishnan et al., 2012; Tromp et al., 2017; Tromp et al., 2018). However, a common pathway of the biomarkers that were associated with poor prognosis in HFpEF patients in previous studies (Hage et al., 2017; Tromp et al., 2017) and our study seems to be the immune system. Our findings need to be confirmed by other studies investigating similar biomarkers.

\section{Difference between clusters: cardiovascular outcome}

In line with previous reports (Chioncel et al., 2017; Hwang, Melenovsky, \& Borlaug, 2014; Vedin et al., 2017), we found that CAD and pulmonary rales were associated with poor outcome. Age and sex were kept in the models by their known prognostic value (Chioncel et al., 2017). After adjustment for these clinical variables, patients in cluster 2 had a worse cardiovascular outcome compared to the patients in cluster 1.

\section{Clinical implications}

This study may have clinical and research implications. More insight into the mechanisms related to poor outcome in $\mathrm{HFpEF}$ is obtained by the finding that the majority of the biomarkers associated with cluster 2 (the cluster with a higher risk for poor CV outcome) seem to be involved in processes related to the immune system, signal transduction cascades, cell interactions and metabolism. Our findings encourage additional studies investigating the underlying mechanisms and their clinical relevance. The biomarkers (and pathways) identified in this study may help select high-risk HFpEF patients which could be helpful for the inclusion or exclusion of patients in future trials. Moreover, our findings may be the basis 
of investigating therapies specifically targeting these pathways and the potential use of corresponding markers potentially identifying patients with distinct mechanistic bioprofiles most likely to respond to the selected mechanistically targeted therapies. Such strategies could remediate the poor track record of past HFpEF large outcome trials (Rossignol et al., 2019).

\section{Strengths and limitations}

A strength of our study is that MEDIA-DHF was a large prospective European cohort in which data on $>400$ biomarkers from different disease domains were collected allowing for an unbiased approach to identify underlying pathophysiological pathways in HFpEF.

The most important limitation of this study is that we could not perform external validation of our prediction model due to the absence of other HFpEF cohorts with similar biomarkers, echocardiographic and follow up data. It is clear that other studies need to confirm our findings. Furthermore, at the time of enrollment, HFpEF was diagnosed following 2007 ESC diagnostic recommendations. Since the 2007 criteria, other criteria have been proposed and it has recently been shown that large variations in prevalence of diastolic dysfunction may be expected according to which criterion is used (Huttin et al., 2017). However, when applying the $\mathrm{H}_{2} \mathrm{FPEF}$ score by Reddy and colleagues(Reddy, Carter, Obokata, Redfield, \& Borlaug, 2018) to the MEDIA-DHF cohort, only $2 \%$ of patients had a low probability of HFpEF whereas $58 \%$ and $40 \%$ of patients had an intermediate or high probability respectively. Third, the biomarker assay does not provide standard concentration units, making comparisons with clinically applied cut-offs difficult. Fourth, although the biomarker assay in this study covers a wide variety of disease domains, the possibility exists that other, now unmeasured, biomarkers may (also) play a role in the pathophysiology of HFpEF. Fifth, although it is biologically plausible that increased activation of processes related to, for example, the immune system may be associated with a poorer outcome in 
HFpEF, it should be noted that reference values (from a healthy population) for most of the candidate biomarkers in this study are lacking. Sixth, although HFpEF is known to be a heterogeneous disease, the $\mathrm{NbClust}$ package identified only 2 clusters based on the available biomarker data. Including more (clinical) data may identify a larger number of clusters. Seventh, due to the observational nature of our study with only few CV events we did not study whether differences in treatment effects (for ACEi/ARBs, BBs, etc.) can be expected for the different clusters. Also, the low number of adverse events and small sample size preclude to obtain robust estimates. Last, our cohort consists of chronic and recently discharged HFpEF patients and results can therefore not be extrapolated to different (sicker) HFpEF populations.

\section{Conclusion}

Unsupervised learning algorithms applied to $>400$ biomarkers in a large cohort of $392 \mathrm{HFpEF}$ patients led to the identification of 2 distinct HFpEF cluster phenotypes. In addition to differences in clinical features between clusters, we found 17 uncorrelated biomarkers with higher expression in cluster 2 compared to cluster 1 . These biomarkers are involved in pathways linked to the immune system, signal transduction cascades, cell interactions and metabolism, that may contribute to different HFpEF phenotypes.

\section{Clinical significance}

- More insight is obtained in the mechanisms related to poor outcome in HFpEF patients since it was demonstrated that biomarkers associated with the high-risk cluster were related to the immune system, signal transduction cascades, cell interactions and metabolism

- Biomarkers (and pathways) identified in this study may help select high-risk HFpEF patients which could be helpful for the inclusion/exclusion of patients in future trials.

- Our findings may be the basis of investigating therapies specifically targeting these pathways and the potential use of corresponding markers potentially identifying patients with distinct mechanistic bioprofiles most likely to respond to the selected mechanistically targeted therapies. 


\section{Disclosures}

This study was supported by a grant from the European Union (FP7-HEALTH-2010MEDIA), by the French Programme Hospitalier de Recherche Clinique (PHRC) and by the RHU Fight-HF, a public grant overseen by the French National Research Agency (ANR) as part of the second "Investissements d'Avenir" program (reference: ANR-15-RHU-0004), the GEENAGE (ANR-15-IDEX-04-LUE) program, by the Contrat de Plan Etat Région Lorraine and FEDER IT2MP.) N-LA was supported by a Miguel Servet contract CP13/00221 from the "Instituto de Salud Carlos III-FEDER". WJP and LvH were supported by CVON, Dutch Heart Foundation, The Hague, The Netherlands (RECONNECT and EARLY-HFpEF projects). AM received speaker's honoraria from Orion, Otsuka, Philips, Roche and Servier. AM received fees as member of advisory board and/or Steering Committee and/or research grant from Adrenomed, Epygon, Neurotronik, Roche, Sanofi and Sphyngotec. AM owns shares in S-Form Pharma. SS acknowledges funding received from the European Society of Cardiology in form of an ESC Research Grant (R-2018-18686). SH was supported by IMI2CARDIATEAM ( $\mathrm{N}^{\circ}$ 821508), research grants from the Netherlands Organization for Scientific Research (NOW; Vidi 91796338), the Netherlands Cardiovascular Research Initiative, an initiative with support of the Dutch Heart Foundation, CVON2016-Early HFPEF, 2015-10, CVON She-PREDICTS, grant 2017-21, CVON Arena-PRIME, 2017-18 and the ERA-Net-CVD project MacroERA, 01KL1706, and FWO G091018N.

\section{Acknowledgments}

We thank other colleagues for their important contributions to the MEDIA study in the participating centres, including the CRB Lorrain for the biobanking, Gabor Kunszt (Oslo University Hospital), Tamas Erdei and Julie Edwards (Cardiff University). 


\section{References}

Almontashiri, N. A., Vilmundarson, R. O., Ghasemzadeh, N., Dandona, S., Roberts, R., Quyyumi, A. A., . . Stewart, A. F. (2014). Plasma PCSK9 levels are elevated with acute myocardial infarction in two independent retrospective angiographic studies. PLoS One, 9(9), e106294. doi:10.1371/journal.pone.0106294

Arcopinto, M., Salzano, A., Giallauria, F., Bossone, E., Isgaard, J., Marra, A. M., . . Cittadini, A. (2017). Growth Hormone Deficiency Is Associated with Worse Cardiac Function, Physical Performance, and Outcome in Chronic Heart Failure: Insights from the T.O.S.CA. GHD Study. PLoS One, 12(1), e0170058. doi:10.1371/journal.pone.0170058

Bayes-Genis, A., Nunez, J., Zannad, F., Ferreira, J. P., Anker, S. D., Cleland, J. G., . . Voors, A. A. (2017). The PCSK9-LDL Receptor Axis and Outcomes in Heart Failure: BIOSTAT-CHF Subanalysis. J Am Coll Cardiol, 70(17), 2128-2136. doi:10.1016/j.jacc.2017.08.057

Berezin, A. E., Kremzer, A. A., Martovitskaya, Y. V., Berezina, T. A., \& Gromenko, E. A. (2016). Pattern of endothelial progenitor cells and apoptotic endothelial cell-derived microparticles in chronic heart failure patients with preserved and reduced left ventricular ejection fraction. EBioMedicine, 4, 86-94. doi:10.1016/j.ebiom.2016.01.018

Blanco-Colio, L. M. (2014). TWEAK/Fn14 Axis: A Promising Target for the Treatment of Cardiovascular Diseases. Front Immunol, 5, 3. doi:10.3389/fimmu.2014.00003

Brankovic, M., Martijn Akkerhuis, K., Mouthaan, H., Constantinescu, A., Caliskan, K., van Ramshorst, J., ... Kardys, I. (2018). Utility of temporal profiles of new cardio-renal and pulmonary candidate biomarkers in chronic heart failure. Int $\mathrm{J}$ Cardiol. doi:10.1016/j.ijcard.2018.08.001

Calderone, A., Castagnoli, L., \& Cesareni, G. (2013). mentha: a resource for browsing integrated protein-interaction networks. Nat Methods, 10(8), 690-691. doi:10.1038/nmeth.2561

Chatr-Aryamontri, A., Oughtred, R., Boucher, L., Rust, J., Chang, C., Kolas, N. K., . . Tyers, M. (2017). The BioGRID interaction database: 2017 update. Nucleic Acids Res, 45(D1), D369-d379. doi:10.1093/nar/gkw1102

Chen, H. N., Wang, D. J., Ren, M. Y., Wang, Q. L., \& Sui, S. J. (2012). TWEAK/Fn14 promotes the proliferation and collagen synthesis of rat cardiac fibroblasts via the NF-small ka, CyrillicB pathway. Mol Biol Rep, 39(8), 8231-8241. doi:10.1007/s11033-012-1671-3

Chioncel, O., Lainscak, M., Seferovic, P. M., Anker, S. D., Crespo-Leiro, M. G., Harjola, V. P., . . Filippatos, G. (2017). Epidemiology and one-year outcomes in patients with chronic heart failure and preserved, mid-range and reduced ejection fraction: an analysis of the ESC Heart Failure Long-Term Registry. Eur J Heart Fail, 19(12), 15741585. doi:10.1002/ejhf.813

Chong, A. Y., Caine, G. J., Freestone, B., Blann, A. D., \& Lip, G. Y. (2004). Plasma angiopoietin-1, angiopoietin-2, and angiopoietin receptor tie-2 levels in congestive heart failure. J Am Coll Cardiol, 43(3), 423-428. doi:10.1016/j.jacc.2003.08.042

Czucz, J., Cervenak, L., Forhecz, Z., Gombos, T., Pozsonyi, Z., Kunde, J., ... Prohaszka, Z. (2011). Serum soluble E-selectin and NT-proBNP levels additively predict mortality in diabetic patients with chronic heart failure. Clin Res Cardiol, 100(7), 587-594. doi:10.1007/s00392-011-0283-6

Damman, K., Valente, M. A., Voors, A. A., O'Connor, C. M., van Veldhuisen, D. J., \& Hillege, H. L. (2014). Renal impairment, worsening renal function, and outcome in patients with heart failure: an updated meta-analysis. Eur Heart $\mathrm{J}$, 35(7), 455-469. doi:10.1093/eurheartj/eht386

Dankiewicz, J., Linder, A., Annborn, M., Rundgren, M., \& Friberg, H. (2013). Heparin-binding protein: an early indicator of critical illness and predictor of outcome in cardiac arrest. Resuscitation, 84(7), 935-939. doi:10.1016/j.resuscitation.2013.01.006

Dehm, S. M., \& Bonham, K. (2004). SRC gene expression in human cancer: the role of transcriptional activation. Biochem Cell Biol, 82(2), 263-274. doi:10.1139/o03-077

Diny, N. L., Hou, X., Barin, J. G., Chen, G., Talor, M. V., Schaub, J., . . Cihakova, D. (2016). Macrophages and cardiac fibroblasts are the main producers of eotaxins and regulate eosinophil trafficking to the heart. Eur J Immunol, 46(12), 2749-2760. doi:10.1002/eji.201646557

Economou, E., Tousoulis, D., Katinioti, A., Stefanadis, C., Trikas, A., Pitsavos, C., . . Toutouzas, P. (2001). Chemokines in patients with ischaemic heart disease and the effect of coronary angioplasty. Int J Cardiol, 80(1), 55-60.

Fabregat, A., Jupe, S., Matthews, L., Sidiropoulos, K., Gillespie, M., Garapati, P., . . D'Eustachio, P. (2018). The Reactome Pathway Knowledgebase. Nucleic Acids Res, 46(D1), D649-d655. doi:10.1093/nar/gkx1132

Ferraccioli, G., \& Gremese, E. (2017). B cell activating factor (BAFF) and BAFF receptors: fakes and facts. Clin Exp Immunol, 190(3), 291-292. doi:10.1111/cei.13039

Franssen, C., Chen, S., Unger, A., Korkmaz, H. I., De Keulenaer, G. W., Tschope, C., . . Hamdani, N. (2016). Myocardial Microvascular Inflammatory Endothelial Activation in Heart Failure With Preserved Ejection Fraction. JACC Heart Fail, 4(4), 312-324. doi:10.1016/j.jchf.2015.10.007

Frazer, J. K., Jackson, D. G., Gaillard, J. P., Lutter, M., Liu, Y. J., Banchereau, J., . . Pascual, V. (2000). Identification of centerin: a novel human germinal center B cell-restricted serpin. Eur J Immunol, 30(10), 3039-3048. doi:10.1002/1521-4141(200010)30:10<3039::aid-immu3039>3.0.co;2-h 
Gautam, N., Olofsson, A. M., Herwald, H., Iversen, L. F., Lundgren-Akerlund, E., Hedqvist, P., . . Lindbom, L. (2001). Heparinbinding protein (HBP/CAP37): a missing link in neutrophil-evoked alteration of vascular permeability. Nat Med, 7(10), 1123-1127. doi:10.1038/nm1001-1123

Hage, C., Michaelsson, E., Linde, C., Donal, E., Daubert, J. C., Gan, L. M., \& Lund, L. H. (2017). Inflammatory Biomarkers Predict Heart Failure Severity and Prognosis in Patients With Heart Failure With Preserved Ejection Fraction: A Holistic Proteomic Approach. Circ Cardiovasc Genet, 10(1). doi:10.1161/circgenetics.116.001633

Hamann, J., Aust, G., Arac, D., Engel, F. B., Formstone, C., Fredriksson, R., . . Schioth, H. B. (2015). International Union of Basic and Clinical Pharmacology. XCIV. Adhesion G protein-coupled receptors. Pharmacol Rev, 67(2), 338-367. doi:10.1124/pr.114.009647

He, Q., \& LaPointe, M. C. (2001). Src and Rac mediate endothelin-1 and lysophosphatidic acid stimulation of the human brain natriuretic peptide promoter. Hypertension, 37(2 Pt 2), 478-484.

Huang, K. Y., \& Lin, H. H. (2018). The Activation and Signaling Mechanisms of GPR56/ADGRG1 in Melanoma Cell. Front Oncol, 8, 304. doi:10.3389/fonc.2018.00304

Huang, R. B., \& Eniola-Adefeso, O. (2012). Shear stress modulation of IL-1beta-induced E-selectin expression in human endothelial cells. PLoS One, 7(2), e31874. doi:10.1371/journal.pone.0031874

Huttin, O., Fraser, A. G., Coiro, S., Bozec, E., Selton-Suty, C., Lamiral, Z., . . . Girerd, N. (2017). Impact of Changes in Consensus Diagnostic Recommendations on the Echocardiographic Prevalence of Diastolic Dysfunction. J Am Coll Cardiol, 69(25), 3119-3121. doi:10.1016/j.jacc.2017.04.039

Hwang, S. J., Melenovsky, V., \& Borlaug, B. A. (2014). Implications of coronary artery disease in heart failure with preserved ejection fraction. J Am Coll Cardiol, 63(25 Pt A), 2817-2827. doi:10.1016/j.jacc.2014.03.034

Ikezoe, K., Ohshima, S., Osoegawa, M., Tanaka, M., Ogawa, K., Nagata, K., \& Kira, J. I. (2006). Expression of granulysin in polymyositis and inclusion-body myositis. J Neurol Neurosurg Psychiatry, 77(10), 1187-1190. doi:10.1136/jnnp.2005.081810

Ivetic, A. (2018). A head-to-tail view of L-selectin and its impact on neutrophil behaviour. Cell Tissue Res, 371(3), 437-453. doi:10.1007/s00441-017-2774-x

Jones, G. T., Phillips, L. V., Williams, M. J., van Rij, A. M., \& Kabir, T. D. (2016). Two C-C Family Chemokines, Eotaxin and RANTES, Are Novel Independent Plasma Biomarkers for Abdominal Aortic Aneurysm. J Am Heart Assoc, 5(5). doi:10.1161/jaha.115.002993

Kao, D. P., Lewsey, J. D., Anand, I. S., Massie, B. M., Zile, M. R., Carson, P. E., . . Lindenfeld, J. (2015). Characterization of subgroups of heart failure patients with preserved ejection fraction with possible implications for prognosis and treatment response. Eur J Heart Fail, 17(9), 925-935. doi:10.1002/ejhf.327

Kibbe, W. A., Arze, C., Felix, V., Mitraka, E., Bolton, E., Fu, G., . . Schriml, L. M. (2015). Disease Ontology 2015 update: an expanded and updated database of human diseases for linking biomedical knowledge through disease data. Nucleic Acids Res, 43(Database issue), D1071-1078. doi:10.1093/nar/gku1011

Kotsch, K., Mashreghi, M. F., Bold, G., Tretow, P., Beyer, J., Matz, M., . . Reinke, P. (2004). Enhanced granulysin mRNA expression in urinary sediment in early and delayed acute renal allograft rejection. Transplantation, 77(12), 18661875.

Kumar, J., Okada, S., Clayberger, C., \& Krensky, A. M. (2001). Granulysin: a novel antimicrobial. Expert Opin Investig Drugs, 10(2), 321-329. doi:10.1517/13543784.10.2.321

Lee, K. W., Lip, G. Y., \& Blann, A. D. (2004). Plasma angiopoietin-1, angiopoietin-2, angiopoietin receptor tie-2, and vascular endothelial growth factor levels in acute coronary syndromes. Circulation, 110(16), 2355-2360. doi:10.1161/01.cir.0000138112.90641.7f

Li, X., Tjwa, M., Moons, L., Fons, P., Noel, A., Ny, A., . . Carmeliet, P. (2005). Revascularization of ischemic tissues by PDGFCC via effects on endothelial cells and their progenitors. J Clin Invest, 115(1), 118-127. doi:10.1172/jci19189

Linder, A., Akesson, P., Inghammar, M., Treutiger, C. J., Linner, A., \& Sunden-Cullberg, J. (2012). Elevated plasma levels of heparin-binding protein in intensive care unit patients with severe sepsis and septic shock. Crit Care, 16(3), R90. doi:10.1186/cc11353

Linder, A., Soehnlein, O., \& Akesson, P. (2010). Roles of heparin-binding protein in bacterial infections. J Innate Immun, 2(5), 431-438. doi:10.1159/000314853

Lu, D., \& Insel, P. A. (2013). Hydrolysis of extracellular ATP by ectonucleoside triphosphate diphosphohydrolase (ENTPD) establishes the set point for fibrotic activity of cardiac fibroblasts. J Biol Chem, 288(26), 19040-19049. doi:10.1074/jbc.M113.466102

Lundberg, M., Eriksson, A., Tran, B., Assarsson, E., \& Fredriksson, S. (2011). Homogeneous antibody-based proximity extension assays provide sensitive and specific detection of low-abundant proteins in human blood. Nucleic Acids Res, 39(15), e102. doi:10.1093/nar/gkr424

Luo, R., Jeong, S. J., Jin, Z., Strokes, N., Li, S., \& Piao, X. (2011). G protein-coupled receptor 56 and collagen III, a receptorligand pair, regulates cortical development and lamination. Proc Natl Acad Sci U S A, 108(31), 12925-12930. doi:10.1073/pnas.1104821108

Ma, X. L., Weyrich, A. S., Lefer, D. J., Buerke, M., Albertine, K. H., Kishimoto, T. K., \& Lefer, A. M. (1993). Monoclonal antibody to $L$-selectin attenuates neutrophil accumulation and protects ischemic reperfused cat myocardium. Circulation, 88(2), 649-658.

Medamana, J., Clark, R. A., \& Butler, J. (2017). Platelet-Derived Growth Factor in Heart Failure. Handb Exp Pharmacol, 243, 355-369. doi:10.1007/164_2016_80 
Moreno, H., Jr., Metze, K., Bento, A. C., Antunes, E., Zatz, R., \& de Nucci, G. (1996). Chronic nitric oxide inhibition as a model of hypertensive heart muscle disease. Basic Res Cardiol, 91(3), 248-255.

Morrison, A. C., Bare, L. A., Luke, M. M., Pankow, J. S., Mosley, T. H., Devlin, J. J., . . Boerwinkle, E. (2008). Single nucleotide polymorphisms associated with coronary heart disease predict incident ischemic stroke in the atherosclerosis risk in communities study. Cerebrovasc Dis, 26(4), 420-424. doi:10.1159/000155637

Nagasawa, M., Ogawa, K., Imashuku, S., \& Mizutani, S. (2007). Serum granulysin is elevated in patients with hemophagocytic lymphohistiocytosis. Int J Hematol, 86(5), 470-473. doi:10.1532/ijh97.07084

Ong, K. L., Hui, N., Januszewski, A. S., Kaakoush, N. O., Xu, A., Fayyad, R., . . Rye, K. A. (2019). High plasma FGF21 levels predicts major cardiovascular events in patients treated with atorvastatin (from the Treating to New Targets [TNT] Study). Metabolism, 93, 93-99. doi:10.1016/j.metabol.2018.11.006

Ornitz, D. M., \& Itoh, N. (2015). The Fibroblast Growth Factor signaling pathway. Wiley Interdiscip Rev Dev Biol, 4(3), $215-$ 266. doi:10.1002/wdev.176

Pardo, J., Perez-Galan, P., Gamen, S., Marzo, I., Monleon, I., Kaspar, A. A., . . Anel, A. (2001). A role of the mitochondrial apoptosis-inducing factor in granulysin-induced apoptosis. J Immunol, 167(3), 1222-1229.

Paulus, W. J., Tschope, C., Sanderson, J. E., Rusconi, C., Flachskampf, F. A., Rademakers, F. E., . . Brutsaert, D. L. (2007). How to diagnose diastolic heart failure: a consensus statement on the diagnosis of heart failure with normal left ventricular ejection fraction by the Heart Failure and Echocardiography Associations of the European Society of Cardiology. Eur Heart J, 28(20), 2539-2550. doi:10.1093/eurheartj/ehm037

Persic, V., Ruzic, A., Miletic, B., Samsa, D. T., Rakic, M., Raljevic, D., .. Laskarin, G. (2012). Granulysin Expression in Lymphocytes that Populate the Peripheral Blood and the Myocardium after an Acute Coronary Event. Scand $\mathrm{J}$ Immunol, 75(2), 231-242. doi:10.1111/j.1365-3083.2011.02646.x

Pinero, J., Bravo, A., Queralt-Rosinach, N., Gutierrez-Sacristan, A., Deu-Pons, J., Centeno, E., . . Furlong, L. I. (2017). DisGeNET: a comprehensive platform integrating information on human disease-associated genes and variants. Nucleic Acids Res, 45(D1), D833-d839. doi:10.1093/nar/gkw943

Ponikowski, P., Voors, A. A., Anker, S. D., Bueno, H., Cleland, J. G. F., Coats, A. J. S., . . van der Meer, P. (2016). 2016 ESC Guidelines for the diagnosis and treatment of acute and chronic heart failure: The Task Force for the diagnosis and treatment of acute and chronic heart failure of the European Society of Cardiology (ESC)Developed with the special contribution of the Heart Failure Association (HFA) of the ESC. Eur Heart J, 37(27), 2129-2200. doi:10.1093/eurheartj/ehw128

Ptaszynska-Kopczynska, K., Marcinkiewicz-Siemion, M., Lisowska, A., Waszkiewicz, E., Witkowski, M., Jasiewicz, M., . . . Kaminski, K. A. (2016). Alterations of soluble TWEAK and CD163 concentrations in patients with chronic heart failure. Cytokine, 80, 7-12. doi:10.1016/j.cyto.2016.02.005

Reddy, Y. N. V., Carter, R. E., Obokata, M., Redfield, M. M., \& Borlaug, B. A. (2018). A Simple, Evidence-Based Approach to Help Guide Diagnosis of Heart Failure With Preserved Ejection Fraction. Circulation, 138(9), 861-870. doi:10.1161/circulationaha.118.034646

Rossignol P, Hernandez AF, Solomon S, Zannad F. Heart failure drug treatment. (2019). Lancet, in press.

Rubin, D. B. (2004). Multiple Imputation for Nonresponse in Surveys. New York: John Wiley and Sons.

Sabatine, M. S., Giugliano, R. P., Keech, A. C., Honarpour, N., Wiviott, S. D., Murphy, S. A., . . Pedersen, T. R. (2017). Evolocumab and Clinical Outcomes in Patients with Cardiovascular Disease. N Engl J Med, 376(18), 1713-1722. doi:10.1056/NEJMoa1615664

Salzano, A., Marra, A. M., Ferrara, F., Arcopinto, M., Bobbio, E., Valente, P., . . Cittadini, A. (2016). Multiple hormone deficiency syndrome in heart failure with preserved ejection fraction. Int J Cardiol, 225, 1-3. doi:10.1016/j.ijcard.2016.09.085

Salzano, A., Marra, A. M., D'Assante, R., Arcopinto, M., Suzuki, T., Bossone, E., \& Cittadini, A. (2018). Growth Hormone Therapy in Heart Failure. Heart Fail Clin, 14(4), 501-515. doi:10.1016/j.hfc.2018.05.002

Sanchez-Martinez, S., Duchateau, N., Erdei, T., Kunszt, G., Aakhus, S., Degiovanni, A., . . Bijnens, B. H. (2018). Machine Learning Analysis of Left Ventricular Function to Characterize Heart Failure With Preserved Ejection Fraction. Circ Cardiovasc Imaging, 11(4), e007138. doi:10.1161/circimaging.117.007138

Sanders-van Wijk, S., van Empel, V., Davarzani, N., Maeder, M. T., Handschin, R., Pfisterer, M. E., \& Brunner-La Rocca, H. P. (2015). Circulating biomarkers of distinct pathophysiological pathways in heart failure with preserved vs. reduced left ventricular ejection fraction. Eur J Heart Fail, 17(10), 1006-1014. doi:10.1002/ejhf.414

Santhanakrishnan, R., Chong, J. P., Ng, T. P., Ling, L. H., Sim, D., Leong, K. T., . . Lam, C. S. (2012). Growth differentiation factor 15, ST2, high-sensitivity troponin $\mathrm{T}$, and $\mathrm{N}$-terminal pro brain natriuretic peptide in heart failure with preserved vs. reduced ejection fraction. Eur J Heart Fail, 14(12), 1338-1347. doi:10.1093/eurjhf/hfs130

Sevigny, J., Sundberg, C., Braun, N., Guckelberger, O., Csizmadia, E., Qawi, I., . . Robson, S. C. (2002). Differential catalytic properties and vascular topography of murine nucleoside triphosphate diphosphohydrolase 1 (NTPDase1) and NTPDase2 have implications for thromboregulation. Blood, 99(8), 2801-2809.

Shah, S. J., Katz, D. H., Selvaraj, S., Burke, M. A., Yancy, C. W., Gheorghiade, M., . . . Deo, R. C. (2015). Phenomapping for novel classification of heart failure with preserved ejection fraction. Circulation, 131(3), 269-279. doi:10.1161/circulationaha.114.010637

Shimada, Y. J., \& Cannon, C. P. (2015). PCSK9 (Proprotein convertase subtilisin/kexin type 9) inhibitors: past, present, and the future. Eur Heart J, 36(36), 2415-2424. doi:10.1093/eurheartj/ehv174 
Slenter, D. N., Kutmon, M., Hanspers, K., Riutta, A., Windsor, J., Nunes, N., . . Willighagen, E. L. (2018). WikiPathways: a multifaceted pathway database bridging metabolomics to other omics research. Nucleic Acids Res, 46(D1), D661d667. doi:10.1093/nar/gkx1064

Smith, T. L., Van Slyke, P., Jones, N., Dumont, D. J., \& McGlade, C. J. (2018). Tie2 signalling through Erk1/2 regulates TLR4 driven inflammation. Cell Signal, 51, 211-221. doi:10.1016/j.cellsig.2018.08.001

Stein, B., Eschenhagen, T., Rudiger, J., Scholz, H., Forstermann, U., \& Gath, I. (1998). Increased expression of constitutive nitric oxide synthase III, but not inducible nitric oxide synthase II, in human heart failure. J Am Coll Cardiol, 32(5), 1179-1186.

Szklarczyk, D., Franceschini, A., Wyder, S., Forslund, K., Heller, D., Huerta-Cepas, J., . . von Mering, C. (2015). STRING v10: protein-protein interaction networks, integrated over the tree of life. Nucleic Acids Res, 43(Database issue), D447452. doi:10.1093/nar/gku1003

Tabassian, M., Sunderji, I., Erdei, T., Sanchez-Martinez, S., Degiovanni, A., Marino, P., . . D'Hooge, J. (2018). Diagnosis of Heart Failure With Preserved Ejection Fraction: Machine Learning of Spatiotemporal Variations in Left Ventricular Deformation. J Am Soc Echocardiogr, 31(12), 1272-1284.e1279. doi:10.1016/j.echo.2018.07.013

Tribouilloy, C., Rusinaru, D., Mahjoub, H., Souliere, V., Levy, F., Peltier, M., . . Massy, Z. (2008). Prognosis of heart failure with preserved ejection fraction: a 5 year prospective population-based study. Eur Heart J, 29(3), 339-347. doi:10.1093/eurheartj/ehm554

Tromp, J., Khan, M. A., Klip, I. T., Meyer, S., de Boer, R. A., Jaarsma, T., ... Voors, A. A. (2017). Biomarker Profiles in Heart Failure Patients With Preserved and Reduced Ejection Fraction. J Am Heart Assoc, 6(4). doi:10.1161/jaha.116.003989

Tromp, J., Westenbrink, B. D., Ouwerkerk, W., van Veldhuisen, D. J., Samani, N. J., Ponikowski, P., . . Voors, A. A. (2018). Identifying Pathophysiological Mechanisms in Heart Failure With Reduced Versus Preserved Ejection Fraction. J Am Coll Cardiol, 72(10), 1081-1090. doi:10.1016/j.jacc.2018.06.050

Tsao, C. W., Lyass, A., Enserro, D., Larson, M. G., Ho, J. E., Kizer, J. R., . . Vasan, R. S. (2018). Temporal Trends in the Incidence of and Mortality Associated With Heart Failure With Preserved and Reduced Ejection Fraction. JACC Heart Fail, 6(8), 678-685. doi:10.1016/j.jchf.2018.03.006

Tsiantoulas, D., Sage, A. P., Goderle, L., Ozsvar-Kozma, M., Murphy, D., Porsch, F., . . Binder, C. J. (2018). B Cell-Activating Factor Neutralization Aggravates Atherosclerosis. Circulation, 138(20), 2263-2273. doi:10.1161/circulationaha.117.032790

UniProt: the universal protein knowledgebase. (2017). Nucleic Acids Res, 45(D1), D158-d169. doi:10.1093/nar/gkw1099

Vedin, O., Lam, C. S. P., Koh, A. S., Benson, L., Teng, T. H. K., Tay, W. T., . . Lund, L. H. (2017). Significance of Ischemic Heart Disease in Patients With Heart Failure and Preserved, Midrange, and Reduced Ejection Fraction: A Nationwide Cohort Study. Circ Heart Fail, 10(6). doi:10.1161/circheartfailure.117.003875

Vitello, A. M., Du, Y., Buttrick, P. M., \& Walker, L. A. (2012). Serendipitous discovery of a novel protein signaling mechanism in heart failure. Biochem Biophys Res Commun, 421(3), 431-435. doi:10.1016/j.bbrc.2012.03.124

Williams, T. J. (2015). Eotaxin-1 (CCL11). Front Immunol, 6, 84. doi:10.3389/fimmu.2015.00084

Woo, Y. C., Xu, A., Wang, Y., \& Lam, K. S. (2013). Fibroblast growth factor 21 as an emerging metabolic regulator: clinical perspectives. Clin Endocrinol (Oxf), 78(4), 489-496. doi:10.1111/cen.12095

Zannad, F., \& Rossignol, P. (2018). Cardiorenal Syndrome Revisited. Circulation, 138(9), 929-944. doi:10.1161/circulationaha.117.028814

Zouggari, Y., Ait-Oufella, H., Bonnin, P., Simon, T., Sage, A. P., Guerin, C., . . . Mallat, Z. (2013). B lymphocytes trigger monocyte mobilization and impair heart function after acute myocardial infarction. Nat Med, 19(10), 1273-1280. doi:10.1038/nm.3284

Zymek, P., Bujak, M., Chatila, K., Cieslak, A., Thakker, G., Entman, M. L., \& Frangogiannis, N. G. (2006). The role of plateletderived growth factor signaling in healing myocardial infarcts. J Am Coll Cardiol, 48(11), 2315-2323. doi:10.1016/j.jacc.2006.07.060 
Table 1

Baseline characteristics of patients according to clusters

\begin{tabular}{|c|c|c|c|c|}
\hline & $\begin{array}{c}\text { Cluster } 1 \\
(\mathrm{~N}=229)\end{array}$ & $\begin{array}{r}\text { Cluster } 2 \\
(\mathrm{~N}=163)\end{array}$ & p-value & $\begin{array}{c}\text { Percentage } \\
\text { missing }\end{array}$ \\
\hline Female sex, n (\%) & $152(66 \%)$ & $98(60 \%)$ & 0.2 & $0 \%$ \\
\hline Age, years, median (IQR) & $73(66-79)$ & $76(69-82)$ & $<0.001$ & $0 \%$ \\
\hline $\begin{array}{l}\text { Recently decompensated chronic } \\
\mathrm{HF}, \mathrm{n}(\%)\end{array}$ & $27(12 \%)$ & $33(20 \%)$ & 0.022 & $0 \%$ \\
\hline Smoking status, n (\%) & & & & $1 \%$ \\
\hline Never & $127(56 \%)$ & $78(48 \%)$ & \multirow{3}{*}{0.16} & \\
\hline Former & $79(35 \%)$ & $71(44 \%)$ & & \\
\hline Current & $22(10 \%)$ & $12(8 \%)$ & & \\
\hline Alcohol consumption, $\mathrm{n}(\%)$ & & & & $1 \%$ \\
\hline Non-consumer & $144(63 \%)$ & $101(64 \%)$ & \multirow{3}{*}{0.4} & \\
\hline 1-2 drinks/day & $76(33 \%)$ & $48(30 \%)$ & & \\
\hline$>2$ drinks/day & $8(4 \%)$ & $10(6 \%)$ & & \\
\hline $\mathrm{BMI}, \mathrm{kg} / \mathrm{m}^{2}$, mean $\pm \mathrm{SD}$ & $30.5 \pm 5.7$ & $30.7 \pm 6.8$ & 0.76 & $1 \%$ \\
\hline $\begin{array}{l}\text { Waist circumference, } \mathrm{cm} \text {, } \\
\text { mean } \pm \mathrm{SD}\end{array}$ & $103.7 \pm 13.0$ & $106.4 \pm 15.3$ & 0.094 & $21 \%$ \\
\hline $\mathrm{SBP}, \mathrm{mmHg}$, mean $\pm \mathrm{SD}$ & $138 \pm 21$ & $136 \pm 26$ & 0.32 & $2 \%$ \\
\hline $\mathrm{DBP}, \mathrm{mmHg}$, mean $\pm \mathrm{SD}$ & $76 \pm 11$ & $72 \pm 12$ & 0.002 & $2 \%$ \\
\hline Pulmonary rales, $\mathrm{n}(\%)$ & $50(22 \%)$ & $39(25 \%)$ & 0.51 & $1 \%$ \\
\hline NYHA class III/IV, n (\%) & $32(14 \%)$ & $41(25 \%)$ & 0.005 & $0 \%$ \\
\hline Peripheral edema, n (\%) & $96(42 \%)$ & $82(50 \%)$ & 0.1 & $1 \%$ \\
\hline Jugular venous distension, $\mathrm{n}(\%)$ & $10(5 \%)$ & $14(9 \%)$ & 0.088 & $3 \%$ \\
\hline Hepatomegaly, n (\%) & $8(4 \%)$ & $5(3 \%)$ & 0.78 & $7 \%$ \\
\hline Fatigue on exertion, $\mathrm{n}(\%)$ & $170(76 \%)$ & $135(84 \%)$ & 0.036 & $2 \%$ \\
\hline Heart rate, bmp, mean \pm SD & $69 \pm 15$ & $71 \pm 14$ & 0.21 & $3 \%$ \\
\hline $\begin{array}{l}\text { Previous HF hospitalization, } \mathrm{n} \\
(\%)\end{array}$ & $65(29 \%)$ & $72(45 \%)$ & 0.001 & $2 \%$ \\
\hline Atrial fibrillation, $\mathrm{n}(\%)$ & $53(24 \%)$ & $64(40 \%)$ & $<0.001$ & $3 \%$ \\
\hline Hypertension, n (\%) & $195(86 \%)$ & $147(91 \%)$ & 0.12 & $1 \%$ \\
\hline Diabetes mellitus, n (\%) & $79(35 \%)$ & $75(46 \%)$ & 0.021 & $0 \%$ \\
\hline Coronary artery disease, $\mathrm{n}(\%)$ & $68(31 \%)$ & $60(38 \%)$ & 0.14 & $3 \%$ \\
\hline Stroke or TIA, n (\%) & $28(12 \%)$ & $16(10 \%)$ & 0.47 & $1 \%$ \\
\hline Peripheral artery disease, $\mathrm{n}(\%)$ & $13(6 \%)$ & $21(13 \%)$ & 0.013 & $2 \%$ \\
\hline COPD, n $(\%)$ & $38(17 \%)$ & $33(21 \%)$ & 0.34 & $2 \%$ \\
\hline \multicolumn{5}{|l|}{$\begin{array}{l}\text { Laboratory measurements, } \\
\text { mean } \pm \text { SD }\end{array}$} \\
\hline Total cholesterol, mg/dL & $181 \pm 39$ & $168 \pm 48$ & 0.015 & $17 \%$ \\
\hline LDLc, mg/dL & $103.2 \pm 33.78$ & $94.1 \pm 41.4$ & 0.042 & $20 \%$ \\
\hline HDLc, $\mathrm{mg} / \mathrm{dL}$ & $56.8 \pm 22.1$ & $48.7 \pm 14.0$ & $<0.001$ & $19 \%$ \\
\hline $\mathrm{Hb}, \mathrm{g} / \mathrm{dL}$ & $13.3 \pm 1.5$ & $12.6 \pm 1.8$ & $<0.001$ & $12 \%$ \\
\hline Anemia, n (\%) & $72(35 \%)$ & $71(50 \%)$ & 0.005 & $12 \%$ \\
\hline $\mathrm{eGFR}, \mathrm{mL} / \mathrm{min} / 1.73 \mathrm{~m} 2$ & $76.3 \pm 20.4$ & $52.6 \pm 21.4$ & $<0.001$ & $6 \%$ \\
\hline \multicolumn{5}{|l|}{$\begin{array}{l}\text { Medication prescription rates, } n \\
(\%)\end{array}$} \\
\hline ACEi or ARB & $192(84 \%)$ & $127(78 \%)$ & 0.15 & $0 \%$ \\
\hline Betablockers & $154(67 \%)$ & $132(81 \%)$ & 0.003 & $0 \%$ \\
\hline
\end{tabular}




\begin{tabular}{|l|c|c|c|c|}
\hline Loop diuretics & $107(47 \%)$ & $128(79 \%)$ & $<0.001$ & $0 \%$ \\
\hline Thiazide diuretics & $61(27 \%)$ & $26(16 \%)$ & 0.013 & $0 \%$ \\
\hline MRA & $20(9 \%)$ & $23(14 \%)$ & 0.096 & $0 \%$ \\
\hline Aspirin & $94(41 \%)$ & $65(40 \%)$ & 0.82 & $0 \%$ \\
\hline Oral anticoagulants & $78(34 \%)$ & $83(51 \%)$ & $<0.001$ & $0 \%$ \\
\hline Insulin & $22(10 \%)$ & $30(18 \%)$ & 0.012 & $0 \%$ \\
\hline Statin & $139(61 \%)$ & $102(63 \%)$ & 0.71 & $0 \%$ \\
\hline $\begin{array}{l}\text { Echocardiographic parameters, } \\
\text { mean } \pm \text { SD }\end{array}$ & & & & \\
\hline e' & $7.2 \pm 2.1$ & $7.5 \pm 2.1$ & 0.18 & $7 \%$ \\
\hline E/e' & $12.7 \pm 4.6$ & $14.2 \pm 5.9$ & 0.008 & $7 \%$ \\
\hline LVEF, $\%$ & $61.2 \pm 7.1$ & $60.2 \pm 6.7$ & 0.15 & $0 \%$ \\
\hline PASP, mmHg & $32.6 \pm 12.5$ & $38.0 \pm 12.4$ & $<0.001$ & $25 \%$ \\
\hline TAPSE, cm & $21.4 \pm 4.5$ & $19.2 \pm 4.9$ & $<0.001$ & $10 \%$ \\
\hline E/A & $1.1 \pm 0.6$ & $1.5 \pm 1.1$ & $<0.001$ & $30 \%$ \\
\hline
\end{tabular}

Legend: HF, heart failure; BMI, body mass index; DM, diabetes mellitus; CAD, coronary artery disease; PAD, peripheral artery disease; COPD, chronic obstructive pulmonary disease; OSAS, obstructive sleep apnea syndrome; TIA, transient ischemic attack; DBP, diastolic blood pressure; SBP, systolic blood pressure; NYHA, New York Heart Association; eGFR, estimated glomerular filtration rate, BNP, brain natriuretic peptide; NT-proBNP, N-terminal pro-brain natriuretic peptide; ASA, acetylsalicylic acid; ACEi, ACE-inhibitor; ARB, angiotensin receptor blocker, $\mathrm{BB}$, betablocker; MRA, mineralocorticoid receptor antagonist; LVEF, left ventricular ejection fraction; E/e', the ratio of mitral inflow velocity and early mitral annulus velocity, PASP, pulmonary artery systolic pressure; TAPSE, Tricuspidal Annular Plane Systolic Excursion; E/A, ratio of the early (E) to late (A) ventricular filling velocities; IQR, interquartile range.

Anemia is defined following the definition of the World Health Organization $(<12 \mathrm{~g} / \mathrm{dL}$ in females and $<13 \mathrm{~g} / \mathrm{dL}$ in males) 
Table 2 Crude and adjusted odds ratios for the association between clinical variables and cluster membership

\begin{tabular}{|l|c|c|c|c|}
\hline $\begin{array}{l}\text { Set of clinical variables associated with } \\
\text { cluster } 2 \text { membership }\end{array}$ & \multicolumn{2}{|c|}{ Univariate analyses } & \multicolumn{2}{c|}{ Multivariate analyses } \\
\hline & OR (95\% CI) & p-value & OR (95\% CI) & p-value \\
\hline Loop diuretics & $4.17(2.65-6.57)$ & $<0.001$ & $2.36(1.41-3.95)$ & 0.001 \\
\hline Betablockers & $2.07(1.29-3.35)$ & 0.003 & $1.86(1.06-3.28)$ & 0.031 \\
\hline Diabetes mellitus & $1.62(1.07-2.44)$ & 0.022 & $1.69(1.02-2.82)$ & 0.042 \\
\hline eGFR, per 1 mL/min/1.73m2 increase & $0.95(0.93-0.96)$ & $<0.001$ & $0.95(0.94-0.97)$ & $<0.001$ \\
\hline Female sex & $0.76(0.50-1.16)$ & 0.21 & $0.77(0.46-1.27)$ & 0.30 \\
\hline Age, per year increase & $1.04(1.02-1.07)$ & $<0.001$ & $1.02(0.99-1.05)$ & 0.17 \\
\hline
\end{tabular}

Legend: eGFR, estimated glomerular filtration rate; OR, odds ratio; CI, confidence interval; AUC, area under the curve. Age \& sex were "forced" in the model. 
Table 3 Multiple testing-corrected and uncorrelated (Pearson correlation $<0.3$ ) biomarkers associated with cluster 2 membership on top of the clinical model

\begin{tabular}{|c|c|c|}
\hline & \multicolumn{2}{|c|}{ Bivariate logistic regression analyses } \\
\hline & OR $(95 \% C I)$ & p-value \\
\hline TIE2 & $19.83(6.53-60.23)$ & $<0.001$ \\
\hline ENTPD2 & $13.21(4.12-42.36)$ & $<0.001$ \\
\hline CCL11 & $6.44(3.15-13.17)$ & $<0.001$ \\
\hline TNFSF13B & $5.39(2.79-10.41)$ & $<0.001$ \\
\hline PDGFC & $5.09(2.27-11.39)$ & $<0.001$ \\
\hline SELL & $4.47(2.42-9.28)$ & $<0.001$ \\
\hline PCSK9 & $4.04(2.14-7.62)$ & $<0.001$ \\
\hline TWEAK & $4.00(2.02-7.94)$ & $<0.001$ \\
\hline NOS3 & $3.46(2.14-5.62)$ & $<0.001$ \\
\hline GNLY & $3.45(1.89-6.29)$ & $<0.001$ \\
\hline SELE & $2.43(1.65-3.58)$ & $<0.001$ \\
\hline SERPINA9 & $2.17(1.49-3.16)$ & $<0.001$ \\
\hline AZU1 & $1.87(1.42-2.45)$ & $<0.001$ \\
\hline SRC & $1.63(1.29-2.05)$ & $<0.001$ \\
\hline ADGRG1 & $1.55(1.26-1.91)$ & $<0.001$ \\
\hline FGF-21 & $1.49(1.23-1.79)$ & $<0.001$ \\
\hline $\mathrm{GH}$ & $1.34(1.16-1.56)$ & $<0.001$ \\
\hline
\end{tabular}

Legend: TIE2, angiopoietin-1 receptor; ENTPD2, ectonucleoside triphosphate diphosphohydrolase 2; CCL11, eotaxin; TNFSF13B, tumor necrosis factor ligand superfamily member 13B; PDGFC, platelet-derived growth factor C; SELL, Lselectin; PCSK9, proprotein convertase subtilisin/kexin type 9; TWEAK, tumor necrosis factor (Ligand) superfamily, member 12; NOS3, nitric oxide synthase; GNLY, granulysin; SELE, E-selectine; SERPINA9, serpin A9; AZU1, azurocidin; SRC, Proto-oncogene tyrosine-protein kinase Src; ADGRG1, adhesion G-protein coupled receptor G1; FGF_21_1, fibroblast growth factor 21; GH, growth hormone. 
Table 4 Overview of the mechanistic significance of biomarkers that were more highly expressed in patients in cluster 2 than in cluster 1

\begin{tabular}{|c|c|c|c|}
\hline \multirow[t]{2}{*}{ Individual biomarker } & \multirow[t]{2}{*}{ Mechanistic significance } & \multicolumn{2}{|c|}{ Previous relevant reports } \\
\hline & & Basic reports & Clinical reports \\
\hline \multicolumn{4}{|l|}{ Immune system } \\
\hline TWEAK & $\begin{array}{l}\text { Belongs to the TNF receptor } \\
\text { superfamily and regulates several } \\
\text { cell functions such as } \\
\text { proliferation, apoptosis, } \\
\text { inflammation, angiogenesis, and } \\
\text { collagen synthesis in cardiac } \\
\text { fibroblasts(Blanco-Colio, } \\
\text { 2014)'(Chen, Wang, Ren, Wang, } \\
\& \text { Sui, 2012; Ptaszynska- } \\
\text { Kopczynska et al., 2016) }\end{array}$ & & $\begin{array}{l}\text { Increased in } \\
\text { HFREF(Ptaszynska- } \\
\text { Kopczynska et al., } \\
\text { 2016). No study in } \\
\text { HFPEF }\end{array}$ \\
\hline TNFSF13B & $\begin{array}{l}\text { Member of the TNF superfamily. } \\
\text { Regulates B- and T-cell } \\
\text { function(Ferraccioli \& Gremese, } \\
\text { 2017) }\end{array}$ & $\begin{array}{l}\text { A key driver of coronary } \\
\text { heart disease and } \\
\text { aggravates } \\
\text { atherosclerosis(Tsiantoulas } \\
\text { et al., 2018) }\end{array}$ & $\begin{array}{l}\text { High levels } \\
\text { associated with poor } \\
\text { prognosis in } \\
\text { MI(Zouggari et al., } \\
2013)\end{array}$ \\
\hline GNLY & $\begin{array}{l}\text { Antimicrobial protein present in } \\
\text { the granules of cytotoxic T } \\
\text { lymphocytes and natural killer } \\
\text { cells(Kumar, Okada, Clayberger, } \\
\& \text { Krensky, 2001) and involved } \\
\text { in apoptosis(Pardo et al., 2001) }\end{array}$ & & $\begin{array}{l}\text { Increased in } \\
\text { infection, auto- } \\
\text { immune disease and } \\
\text { after NSTEMI } \\
\text { (Ikezoe et al., 2006; } \\
\text { Kotsch et al., 2004; } \\
\text { Nagasawa, Ogawa, } \\
\text { Imashuku, \& } \\
\text { Mizutani, 2007; } \\
\text { Persic et al., 2012) }\end{array}$ \\
\hline AZU1 & $\begin{array}{l}\text { Stored in neutrophil granules. } \\
\text { Acts as an inflammatory } \\
\text { mediator inducing endothelial } \\
\text { leakage(Gautam et al., 2001; } \\
\text { Linder, Soehnlein, \& Akesson, } \\
\text { 2010) }\end{array}$ & & $\begin{array}{l}\text { Early indicator of } \\
\text { organ dysfunction } \\
\text { after infection } \\
\text { (Linder et al., 2012) } \\
\text { and cardiac } \\
\text { arrest(Dankiewicz, } \\
\text { Linder, Annborn, } \\
\text { Rundgren, \& Friberg, } \\
\text { 2013). Serial } \\
\text { measurements } \\
\text { predicted poor } \\
\text { outcome in chronic } \\
\text { HF(Brankovic et al., } \\
\text { 2018) }\end{array}$ \\
\hline CCL11 & Eosinophil chemoattractant & $\begin{array}{l}\text { Plays a role in the } \\
\text { pathogenesis of several } \\
\text { allergic conditions (e.g. } \\
\text { asthma)(Williams, 2015) }\end{array}$ & $\begin{array}{l}\text { Increased in } \\
\text { eosinophilic } \\
\text { myocarditis(Diny et } \\
\text { al., 2016), abdominal } \\
\text { aortic aneurysms } \\
\text { (Jones, Phillips, } \\
\text { Williams, van Rij, \& } \\
\text { Kabir, 2016) and } \\
\text { CAD (Economou et } \\
\text { al., 2001). }\end{array}$ \\
\hline
\end{tabular}




\begin{tabular}{|c|c|c|c|}
\hline NOS3 & $\begin{array}{l}\text { Enzyme that synthesizes nitric } \\
\text { oxide, primarily in the vascular } \\
\text { endothelium }\end{array}$ & $\begin{array}{l}\text { Inhibition promotes } \\
\text { hypertension and causes } \\
\text { cardiac ischemia in } \\
\text { rats(Moreno et al., 1996) }\end{array}$ & $\begin{array}{l}\text { Increased expression } \\
\text { in ventricular } \\
\text { myocardium of end- } \\
\text { stage dilated, } \\
\text { ischemic and } \\
\text { postmyocarditis CMP } \\
\text { (Stein et al., 1998) }\end{array}$ \\
\hline SERPINA9 & $\begin{array}{l}\text { Maturation and maintenance of } \\
\text { b-cells (Frazer et al., 2000) }\end{array}$ & & $\begin{array}{l}\text { SNPs in the } \\
\text { SERPINA9 gene } \\
\text { have been associated } \\
\text { with incident CAD } \\
\text { and ischemic stroke } \\
\text { (Morrison et al., } \\
\text { 2008). No studies in } \\
\text { HF. }\end{array}$ \\
\hline SELL & $\begin{array}{l}\text { Cell surface adhesion protein } \\
\text { which mediates the adherence of } \\
\text { lymphocytes to endothelial } \\
\text { cells(Ivetic, 2018) }\end{array}$ & $\begin{array}{l}\text { Inhibition in a feline } \\
\text { model of reperfusion- } \\
\text { ischemia prevented } \\
\text { neutrophil accumulation } \\
\text { and endothelial } \\
\text { dysfunction, and reduced } \\
\text { myocardial necrosis(Ma et } \\
\text { al., 1993) } \\
\end{array}$ & Yet to be established. \\
\hline \multicolumn{4}{|l|}{$\begin{array}{l}\text { Signal transduction \& } \\
\text { cell-interactions }\end{array}$} \\
\hline TIE2 & $\begin{array}{l}\text { Receptor that is activated after } \\
\text { binding of angiopoietin- } 1 \text { and } \\
\text { exerts mainly anti-inflammatory } \\
\text { properties by promoting vascular } \\
\text { integrity(Smith, Van Slyke, } \\
\text { Jones, Dumont, \& McGlade, } \\
\text { 2018) }\end{array}$ & & $\begin{array}{l}\text { Elevated levels were } \\
\text { associated with } \\
\text { HFpEF(Berezin, } \\
\text { Kremzer, } \\
\text { Martovitskaya, } \\
\text { Berezina, \& } \\
\text { Gromenko, 2016) and } \\
\text { higher in MI and } \\
\text { HFrEF vs. controls } \\
\text { (Chong, Caine, } \\
\text { Freestone, Blann, \& } \\
\text { Lip, 2004; Lee, Lip, } \\
\text { \& Blann, 2004). The } \\
\text { prognostic } \\
\text { implications of TIE2 } \\
\text { in MI and HF have } \\
\text { yet to be studied. }\end{array}$ \\
\hline SRC & $\begin{array}{l}\text { Proto-oncogene that promotes } \\
\text { survival, angiogenesis, } \\
\text { proliferation and invasion (Dehm } \\
\& \text { Bonham, 2004) }\end{array}$ & $\begin{array}{l}\text { Mediates BNP gene } \\
\text { expression by endothelin-1 } \\
\text { in human myocytes }(\mathrm{He} \& \\
\text { LaPointe, 2001) }\end{array}$ & $\begin{array}{l}\text { Upregulated in } \\
\text { human failing } \\
\text { hearts(Vitello, Du, } \\
\text { Buttrick, \& Walker, } \\
\text { 2012) }\end{array}$ \\
\hline SELE & $\begin{array}{l}\text { A selectin cell adhesion molecule } \\
\text { expressed on endothelial cells. } \\
\text { Recruits leukocytes to the site of } \\
\text { injury during inflammation or } \\
\text { after shear stress (e.g. during } \\
\text { ischemia/reperfusion injury(R. B. } \\
\text { Huang \& Eniola-Adefeso, } \\
\text { 2012)). }\end{array}$ & $\begin{array}{l}\text { Upregulated in the } \\
\text { myocardium of HFPEF } \\
\text { patients(Franssen et al., } \\
\text { 2016) }\end{array}$ & $\begin{array}{l}\text { Predicted mortality in } \\
\text { diabetic HF } \\
\text { patients(Czucz et al., } \\
\text { 2011) }\end{array}$ \\
\hline
\end{tabular}




\begin{tabular}{|c|c|c|c|}
\hline PDGFC & $\begin{array}{l}\text { Activates several pathways } \\
\text { promoting cell survival and } \\
\text { angiogenesis(Medamana, Clark, } \\
\& \text { Butler, 2017) }\end{array}$ & $\begin{array}{l}\text { Critical regulator of post- } \\
\text { MI repair processes } \\
\text { (including collagen } \\
\text { deposition in the } \\
\text { infarct)(Zymek et al., } \\
\text { 2006) and PDGFC } \\
\text { infusion enhanced post- } \\
\text { ischemic revascularization } \\
\text { of the heart in a murine } \\
\text { model(Li et al., 2005). }\end{array}$ & Yet to be established. \\
\hline ADGRG1 & $\begin{array}{l}\text { Plays a role in the early } \\
\text { interaction between neurons and } \\
\text { the pial basement membrane and } \\
\text { hence in cerebral cortical } \\
\text { development(Hamann et al., } \\
\text { 2015) but also in other } \\
\text { developmental processes such as } \\
\text { muscle cell differentiation, male } \\
\text { fertility, immune regulation and } \\
\text { tumorigenesis(K. Y. Huang \& } \\
\text { Lin, 2018). }\end{array}$ & $\begin{array}{l}\text { One of its ligands is } \\
\text { collagen type III which } \\
\text { plays a role in myocardial } \\
\text { fibrosis (Luo et al., 2011) }\end{array}$ & Yet to be established. \\
\hline FGF21 & $\begin{array}{l}\text { Family of signaling proteins that } \\
\text { regulate reproduction, } \\
\text { development and metabolism } \\
\text { (glucose and lipid) by activating } \\
\text { the FGF receptor family of } \\
\text { membrane spanning receptor } \\
\text { tyrosine kinases (Ornitz \& Itoh, } \\
\text { 2015). }\end{array}$ & $\begin{array}{l}\text { Anti-inflammatory, anti- } \\
\text { diabetic and hypolipidemic } \\
\text { effects in animal } \\
\text { studies(Woo, Xu, Wang, } \\
\text { \& Lam, 2013) }\end{array}$ & $\begin{array}{l}\text { Elevated in metabolic } \\
\text { disorders and } \\
\text { CAD(Woo et al., } \\
\text { 2013). High levels } \\
\text { predict CV outcome } \\
\text { in stable CAD (Ong } \\
\text { et al., 2019) } \\
\text { Hypothesis for } \\
\text { differential effects in } \\
\text { animal and clinical } \\
\text { studies: potential } \\
\text { FGF21 resistance in } \\
\text { human disease(Ong } \\
\text { et al., 2019). }\end{array}$ \\
\hline \multicolumn{4}{|l|}{ Metabolism } \\
\hline PCSK9 & $\begin{array}{l}\text { Binds the LDL receptor at the } \\
\text { surface of hepatocytes which } \\
\text { prevents LDL receptor recycling } \\
\text { and hence reduces LDL- } \\
\text { cholesterol clearance (Shimada \& } \\
\text { Cannon, 2015) }\end{array}$ & & $\begin{array}{l}\text { Elevated levels were } \\
\text { associated with poor } \\
\text { outcomes in MI and } \\
\text { HFrEF(Almontashiri } \\
\text { et al., 2014; Bayes- } \\
\text { Genis et al., 2017). } \\
\text { Inhibition improved } \\
\text { outcomes of patients } \\
\text { with atherosclerosis } \\
\text { and elevated } \\
\text { LDL(Sabatine et al., } \\
\text { 2017) }\end{array}$ \\
\hline
\end{tabular}




\begin{tabular}{|c|c|c|c|}
\hline $\mathrm{GH}$ & $\begin{array}{l}\text { Stimulates growth, reproduction } \\
\text { and regeneration but also plays a } \\
\text { role in maintaining the structure } \\
\text { and function of the heart and } \\
\text { regulating the vascular } \\
\text { tone(Salzano et al., 2018) }\end{array}$ & & $\begin{array}{l}\text { GH deficiency is } \\
\text { common in HFrEF } \\
\text { and associated with } \\
\text { larger left ventricular } \\
\text { volumes, higher } \\
\text { filling pressures and } \\
\text { higher mortality risk } \\
\text { vs. HF patients with } \\
\text { normal GH } \\
\text { levels(Arcopinto et } \\
\text { al., 2017). A GH } \\
\text { deficiency is also } \\
\text { observed in HFpEF } \\
\text { patients, but to a } \\
\text { lesser extent(Salzano } \\
\text { et al., 2016). Our } \\
\text { findings suggest an } \\
\text { association in the } \\
\text { other direction. }\end{array}$ \\
\hline ENTPD2 & $\begin{array}{l}\text { Transmembrane protein } \\
\text { expressed in the vasculature, } \\
\text { mainly by microvascular } \\
\text { pericytes, adventitial cells in } \\
\text { muscularised vessels, and by } \\
\text { distinct cell populations in the } \\
\text { subendocardial space(Sevigny et } \\
\text { al., 2002) }\end{array}$ & $\begin{array}{l}\text { Promotes platelet } \\
\text { microthrombus formation } \\
\text { following vascular } \\
\text { injury(Sevigny et al., } \\
\text { 2002) and the attenuation } \\
\text { of profibrotic nucleotide } \\
\text { signaling in cardiac } \\
\text { fibroblasts (Lu \& Insel, } \\
\text { 2013) }\end{array}$ & $\begin{array}{l}\text { The role of ENTPD2 } \\
\text { in human HF has yet } \\
\text { to be established. }\end{array}$ \\
\hline
\end{tabular}

TNF, tumor necrosis factor; MI, myocardial infarction; HFREF, heart failure with reduced ejection fraction; HFPEF, heart failure with preserved ejection fraction; CAD, coronary artery disease; CMP, cardiomyopathy; SNPs single nucleotide polymorphisms, MI myocardial infarction, NSTEMI non-ST segment elevation myocardial infarction; BNP, brain natriuretic peptide; LDL, low-density lipoprotein; TIE2, angiopoietin-1 receptor; ENTPD2, ectonucleoside triphosphate diphosphohydrolase 2; CCL11, eotaxin; TNFSF13B, tumor necrosis factor ligand superfamily member 13B; PDGFC, platelet-derived growth factor C; SELL, L-selectin; PCSK9, proprotein convertase subtilisin/kexin type 9; TWEAK, tumor necrosis factor (Ligand) superfamily, member 12; NOS3, nitric oxide synthase; GNLY, granulysin; SELE, E-selectine; SERPINA9, serpin A9; AZU1, azurocidin; SRC, Proto-oncogene tyrosine-protein kinase Src; ADGRG1, adhesion G-protein coupled receptor G1; FGF-21, fibroblast growth factor 21; GH, growth hormone. 


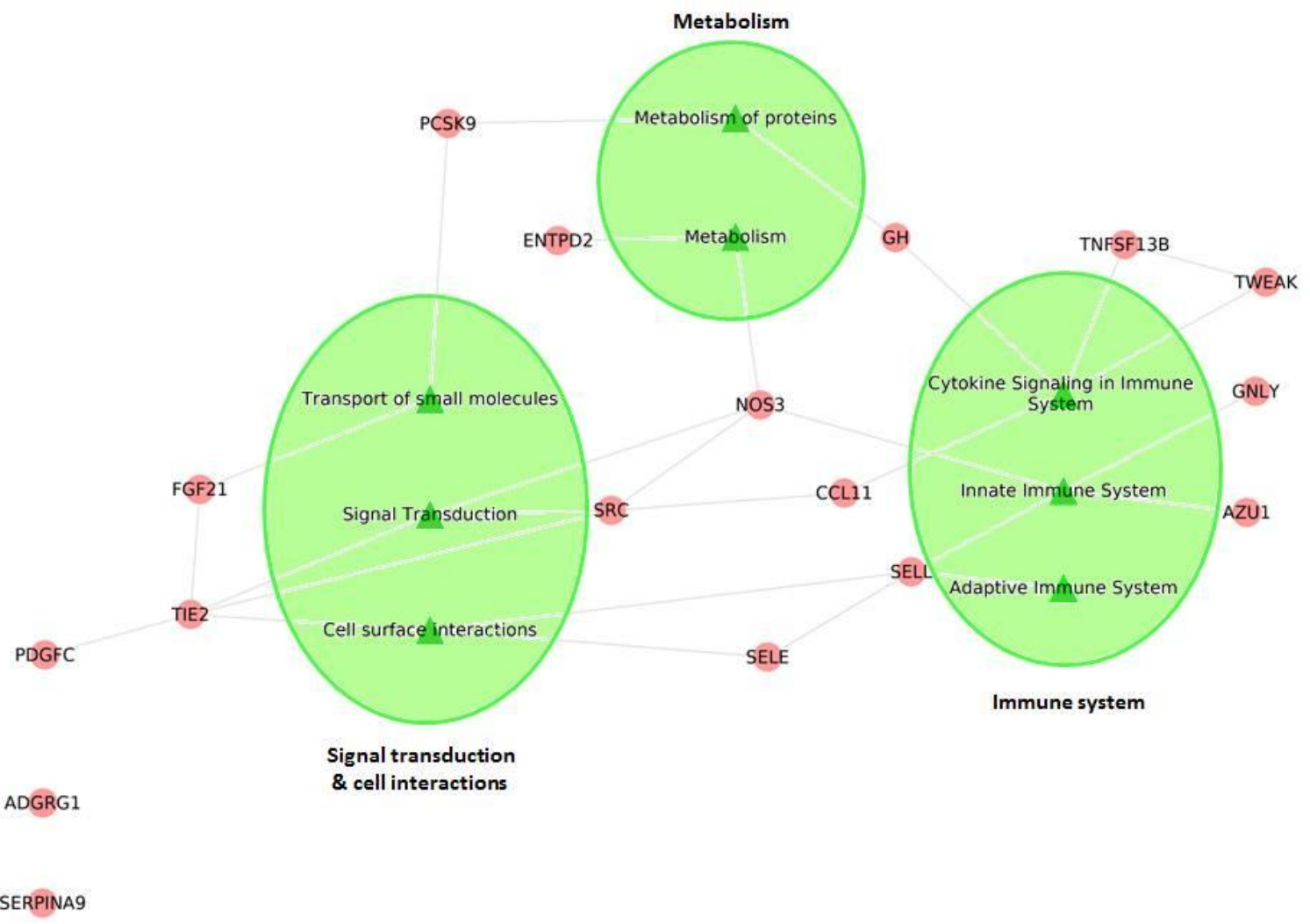

Figure legend. The FHF-GKB (Fight Heart Failure - Graph Knowledge Box) complex network was used to extract available knowledge about human protein-protein and protein-pathway relationships from public resources in order to explore pathways that could connect together biomarker nodes of interest. Queries were expressed according to query patterns defining a path structure between two nodes such as BM-BM and BM-pathway-BM and BMpathway, where the BM nodes are taken from a list of interest. The resulting graphs were merged in a figure illustrating all possible paths not longer than two edges, connecting biomarkers through pathways and proteins. This graph depicts interactions between biomarkers: biomarker - biomarker, biomarker - pathway - biomarker and biomarker - pathway. Pink: biomarkers; Green: pathways. Two out of 17 biomarkers were not linked. 
CV death / CV readmissions

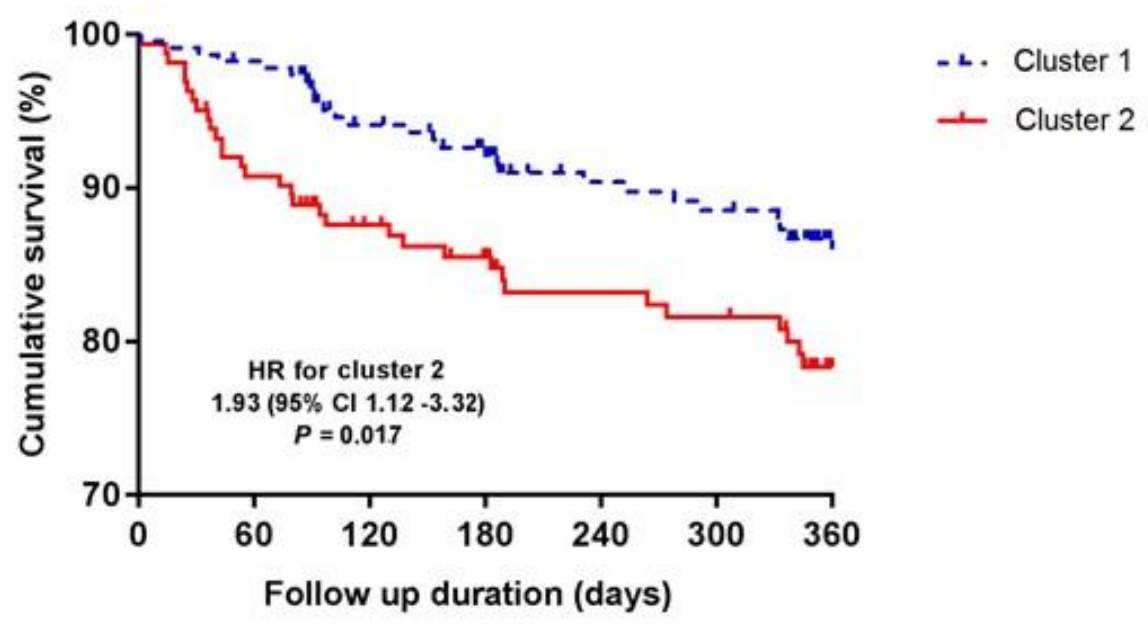

No. at Risk

Cluster 1

Cluster 2 
At baseline, echocardiography was performed in all patients and images were stored in a digital cine-loop format for off-line analysis following recommendations of the American Society of Echocardiography and the European Association of Cardiovascular Imaging relative to the cardiac chamber and right heart measurements ${ }^{1}$

From standard 2D views, left ventricular (LV) structure and function were evaluated (including apical four-chamber, apical two-chamber and parasternal long- and short-axis views). Ventricular dimensions, wall thickness, mass and geometry were determined from 2D parasternal short- and long-axis views. LV volumes, stroke volume and ejection fraction were calculated using the biplane method (modified Simpson's rule). All cardiac chamber volumes and mass measurements were indexed to body surface area.

Left atrial (LA) volume was assessed by the biplane area-length method from apical 2and 4-chamber views at end-systole and was indexed to body surface area (LA volume index, LAVi). LA area $\left(\mathrm{cm}^{2}\right)$ was estimated from the apical views. If LA volume was not available, LA area was used to evaluate remodeling. Patients with either $\mathrm{LAVi}>40 \mathrm{ml} / \mathrm{m}^{2}$ or $\mathrm{LA}$ area $>20 \mathrm{~cm}^{2}$ were considered to have dilated LA.

Pulsed-wave Doppler obtained at the tip of mitral leaflets was used to assess the peak velocities of early (E) and late (A) wave of transmitral flow and E-wave deceleration time (DT). The average of septal and lateral annular velocities (e') was measured using tissue Doppler imaging (TDI). The peak E-wave velocity and the average of septal and lateral e' were used to calculate the E/e'ratio. LV outflow tract (LVOT) time velocity integral, isovolumic relaxation time (IVRT) and color M-mode of early diastolic mitral inflow into the left ventricle (Flow propagation velocity, $\mathrm{Vp}$ ) were acquired from apical four- and five-

\footnotetext{
${ }^{1}$ Lang RM et al. Recommendations for cardiac chamber quantification by echocardiography in adults: an update from the American Society of Echocardiography and the European Association of Cardiovascular Imaging. Eur Heart J Cardiovasc Imaging 2015; 16(3):233-70.
} 
chamber views. Pulmonary venous flow (PVF) was sampled using pulsed-wave Doppler at 1 $\mathrm{cm}$ into the orifice of the right upper pulmonary vein.

TAPSE (in $\mathrm{mm}$ ) measurement was performed to estimate right ventricular (RV) function and pulmonary arterial systolic pressure (PASP) was calculated using the peak velocity of tricuspid regurgitation (TR) and the maximum IVC diameter (IVC baseline) and respiratory variation (Ratio IVC inspiration / IVC baseline) measured $3 \mathrm{~cm}$ before merger with the right atrium.

Overall, echocardiographic data were complete in $>75 \%$ of patients, except for A (and E/A ratio) (which were available in $70 \%$ and $61 \%$ of the population, respectively). 
Nancy Clinical Investigation Centre, University of Lorraine, France (and EDDH European

Drug Development Hub, Nancy, France as project manager)

Lariboisière Hospital, Paris, France

Free University Medical Centre, Amsterdam, The Netherlands

CHARITE, universitätsmedizin Berlin, Berlin Germany

University of Porto, Porto, Portugal

University of Maastricht, Maastricht, The Netherlands

Hartcentrum ZNA, Antwerp, Belgium

Cardiff University, Cardiff, United Kingdom

Foundation for Applied Medical Research, Pamplona, Spain

University of Eastern PIEMONTE Medical School, Novara, Italy

University of Brescia, Brescia, Italy

University of Perugia, Perugia, Italy

University College Dublin, National University of Ireland, Dublin, Ireland

University Debrecen, Debrecen, Hungary

Oslo University Hospital, Norway 


\section{Supplemental table 2 Overview of biomarkers measured at baseline in MEDIA-DHF}

\section{Organ damage panel}

5'-AMP-activated protein kinase subunit beta-1 (PRKAB1) Q9Y478

Adhesion G-protein coupled receptor G1 (ADGRG1) Q9Y653

Aldehyde dehydrogenase, dimeric NADP-preferring (ALDH3A1)

P30838

Anterior gradient protein 2 homolog (AGR2) O95994

Apoptosis-inducing factor 1, mitochondrial (AIFM1) O95831

B-cell scaffold protein with ankyrin repeats (BANK1) Q8NDB2

BH3-interacting domain death agonist (BID) P55957

BMP and activin membrane-bound inhibitor homolog (BAMBI) Q13145

Calcitonin (CALCA) P01258

Calreticulin (CALR) P27797

Carbonic anhydrase 12 (CA12) O43570

Carbonic anhydrase 14 (CA14) Q9ULX7

Casein kinase I isoform delta (CSNK1D) P48730

Claspin (CLSPN) Q9HAW4

CMP-N-acetylneuraminate-beta-galactosamide-alpha-2,3-

sialyltransferase 1 (ST3GAL1)

Q11201

Cocaine esterase (CES2) O00748

Contactin-2 (CNTN2) Q02246

Corticoliberin (CRH) P06850

C-type lectin domain family 1 member A (CLEC1A) Q8NC01

C-type natriuretic peptide (NPPC) P23582

Desmoglein-4 (DSG4) Q86SJ6

Dipeptidyl aminopeptidase-like protein 6 (DPP6) P42658

DNA topoisomerase 2-beta (TOP2B) Q02880

Ectonucleoside triphosphate diphosphohydrolase 2 (ENTPD2) Q9Y5L3

Ectonucleoside triphosphate diphosphohydrolase 6 (ENTPD6) O75354

EGF-like repeat and discoidin I-like domain-containing protein 3

(EDIL3) O43854

Enteropeptidase (TMPRSS15) P98073

Epidermal growth factor-like protein 7 (EGFL7) Q9UHF1

Erbin (ERBIN) Q96RT1

Erythropoietin (EPO) P01588

Fatty acid-binding protein 9 (FABP9) Q0Z7S8

Forkhead box protein O1 (FOXO1) Q12778

Fructose-2,6-bisphosphatase TIGAR (TIGAR) Q9NQ88

Hematopoietic prostaglandin D synthase (HPGDS) O60760

Inactive tyrosine-protein kinase 7 (PTK7) Q13308

Integrin beta-1-binding protein 1 (ITGB1BP1) O14713

Interferon-inducible double-stranded RNA-dependent protein

kinase activator A (PRKRA) O75569

Renin receptor (ATP6AP2) O75787
Kidney Injury Molecule (KIM1) Q96D42

Leukotriene A-4 hydrolase (LTA4H) P09960

Linker for activation of T-cells family member 2 (LAT2) Q9GZY6

Lutropin subunit beta (LHB) P01229

Macrophage erythroblast attacher (MAEA) Q7L5Y9

Macrophage-capping protein (CAPG) P40121

Melanoma-associated antigen D1 (MAGED1) Q9Y5V3

Methionine aminopeptidase 1 (METAP1) P53582

Mevalonate kinase (MVK) Q03426

Mitogen-activated protein kinase kinase kinase kinase 5 (MAP4K5)

Q9Y4K4

Mothers against decapentaplegic homolog 1 (SMAD1) Q15797

NAD-dependent protein deacylase sirtuin-5, mitochondrial (SIRT5)

Q9NXA8

NEDD8 ultimate buster 1 (NUB1) Q9Y5A7

Neutrophil cytosol factor 2 (NCF2) P19878

Nibrin (NBN) O60934

Nitric oxide synthase, endothelial (NOS3) P29474

Nucleobindin-2 (NUCB2) P80303

Parvalbumin alpha (PVALB) P20472

Paxillin (PXN) P49023

Peptidyl-prolyl cis-trans isomerase FKBP1B (FKBP1B) P68106

Perilipin-1 (PLIN1) O60240

Placenta growth factor (PGF) P49763

Platelet-derived growth factor C (PDGFC) Q9NRA1

Pleiotrophin (PTN) P21246

Phosphatidylinositol 3,4,5-trisphosphate 5-phosphatase 2 (INPPL1) O15357

Plexin domain-containing protein 1 (PLXDC1) Q8IUK5

Polypeptide N-acetylgalactosaminyltransferase 10 (GALNT10) Q86SR1

Probetacellulin (BTC) P35070

Programmed cell death protein 1 (PDCD1) Q15116

Prolow-density lipoprotein receptor-related protein 1 (LRP1) Q07954

Proteasome subunit alpha type-1 (PSMA1) P25786

Protein amnionless (AMN) Q9BXJ7

Protein fosB (FOSB) P53539

Protein max (MAX) P61244

Protein phosphatase 1B (PPM1B) O75688

[Pyruvate dehydrogenase [acetyl-transferring]]-phosphatase 1,

mitochondrial (PDP1) Q9P0J1

Ras association domain-containing protein 2 (RASSF2) P50749

Ras GTPase-activating protein 1 (RASA1) P20936

Receptor-type tyrosine-protein phosphatase eta (PTPRJ) Q12913

EGF-containing fibulin-like extracellular matrix protein 1 (EFEMP1) 


\begin{tabular}{|c|c|}
\hline & Q12805 \\
\hline REST corepressor 1 (RCOR1) Q9UKL0 & Endoglin (ENG) P17813 \\
\hline Retinoic acid receptor responder protein 1 (RARRES1) P49788 & Fetuin-B (FETUB) Q9UGM5 \\
\hline Serpin A9 (SERPINA9) Q86WD7 & Glutaminyl-peptide cyclotransferase (QPCT) Q16769 \\
\hline Serum paraoxonase/arylesterase 2 (PON2) Q15165 & Granulysin (GNLY) P22749 \\
\hline Syntaxin-binding protein 3 (STXBP3) O00186 & Hepatocyte growth factor receptor (MET) P08581 \\
\hline Troponin I, cardiac muscle (TNNI3) P19429 & Ig lambda-2 chain C regions (IGLC2) P0CG05 \\
\hline Tyrosine-protein kinase Fes/Fps (FES) P07332 & Insulin-like growth factor-binding protein 3 (IGFBP3) P17936 \\
\hline Tyrosine-protein kinase Fgr (FGR) P09769 & Insulin-like growth factor-binding protein 6 (IGFBP6) P24592 \\
\hline Tyrosine-protein kinase Yes (YES1) P07947 & Integrin alpha-M (ITGAM) P11215 \\
\hline Wiskott-Aldrich syndrome protein (WAS) P42768 & Interleukin-7 receptor subunit alpha (IL7R) P16871 \\
\hline & $\begin{array}{l}\text { Latent-transforming growth factor beta-binding protein } 2 \text { (LTBP2) } \\
\text { Q14767 }\end{array}$ \\
\hline Cardiometabolic panel & $\begin{array}{l}\text { Leukocyte immunoglobulin-like receptor subfamily B member } 1 \\
\text { (LILRB1) Q8NHL6 }\end{array}$ \\
\hline Angiogenin (ANG) P03950 & $\begin{array}{l}\text { Leukocyte immunoglobulin-like receptor subfamily B member } 2 \\
\text { (LILRB2) Q8N423 }\end{array}$ \\
\hline Angiopoietin-related protein 3 (ANGPTL3) Q9Y5C1 & $\begin{array}{l}\text { Leukocyte immunoglobulin-like receptor subfamily B member } 5 \\
\text { (LILRB5) O75023 }\end{array}$ \\
\hline Apolipoprotein M (APOM) O95445 & Lithostathine-1-alpha (REG1A) P05451 \\
\hline Beta-Ala-His dipeptidase (CNDP1) Q96KN2 & Liver carboxylesterase 1 (CES1) P23141 \\
\hline Cartilage acidic protein 1 (CRTAC1) Q9NQ79 & Mannose-binding protein C (MBL2) P11226 \\
\hline Cartilage oligomeric matrix protein (COMP) P49747 & Mast/stem cell growth factor receptor Kit (KIT) P10721 \\
\hline C-C motif chemokine 5 (CCL5) P13501 & Membrane cofactor protein (CD46) P15529 \\
\hline C-C motif chemokine 14 (CCL14) Q16627 & Membrane primary amine oxidase (AOC3) Q16853 \\
\hline C-C motif chemokine 18 (CCL18) P55774 & Metalloproteinase inhibitor 1 (TIMP1) P01033 \\
\hline CD59 glycoprotein (CD59) P13987 & Microfibrillar-associated protein 5 (MFAP5) Q13361 \\
\hline Coagulation factor VII (F7) P08709 & $\begin{array}{l}\text { Multiple epidermal growth factor-like domains protein } 9 \text { (MEGF9) } \\
\text { Q9H1U4 }\end{array}$ \\
\hline Coagulation factor XI (F11) P03951 & Neural cell adhesion molecule 1 (NCAM1) P13591 \\
\hline Collagen alpha-1(XVIII) chain (COL18A1) P39060 & Neural cell adhesion molecule L1-like protein (CHL1) O00533 \\
\hline $\begin{array}{l}\text { Complement C1q tumor necrosis factor-related protein 1 (C1QTNF1) } \\
\text { Q9BXJ1 }\end{array}$ & Neurogenic locus notch homolog protein 1 (NOTCH1) P46531 \\
\hline Complement C2 (C2) P06681 & Neuropilin-1 (NRP1) O14786 \\
\hline Complement factor H-related protein 5 (CFHR5) Q9BXR6 & Neutrophil defensin 1 (DEFA1) P59665 \\
\hline Complement receptor type 2 (CR2) P20023 & Neutrophil gelatinase-associated lipocalin (LCN2) P80188 \\
\hline Cystatin-C (CST3) P01034 & Nidogen-1 (NID1) P14543 \\
\hline Dipeptidyl peptidase 4 (DPP4) P27487 & Oncostatin-M-specific receptor subunit beta (OSMR) Q99650 \\
\hline
\end{tabular}




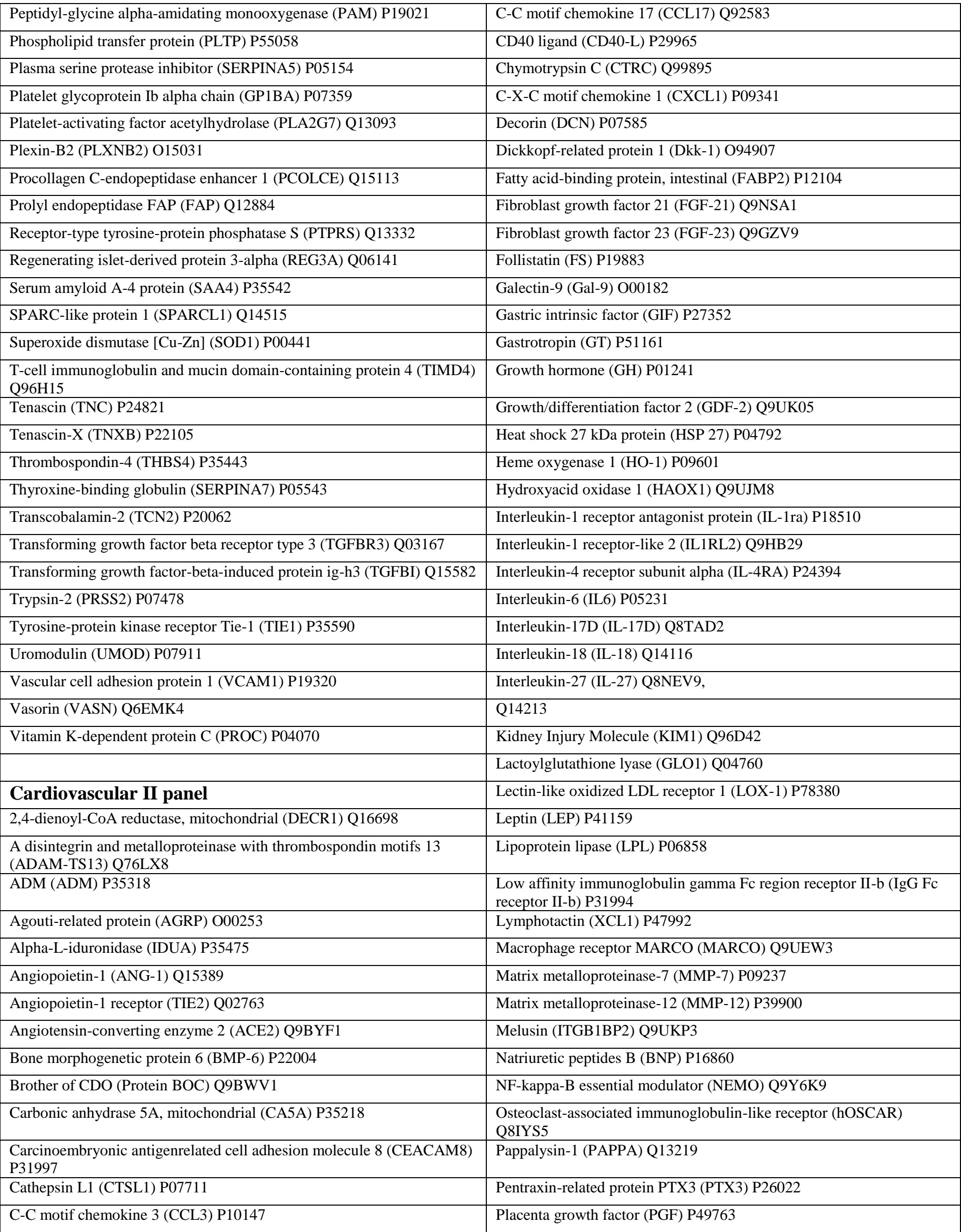




\begin{tabular}{|c|c|}
\hline Platelet-derived growth factor subunit B (PDGF subunit B) P01127 & Caspase-3 (CASP-3) P42574 \\
\hline Poly [ADP-ribose] polymerase 1 (PARP-1) P09874 & Cathepsin D (CTSD) P07339 \\
\hline Polymeric immunoglobulin receptor (PIgR) P01833 & Cathepsin Z (CTSZ) Q9UBR2 \\
\hline Proheparin-binding EGF-like growth factor (HB-EGF) Q99075 & C-C motif chemokine 16 (CCL16) O15467 \\
\hline Pro-interleukin-16 (IL16) Q14005 & Note: New assay under development N/A \\
\hline Prostasin (PRSS8) Q16651 & CD166 antigen (ALCAM) Q13740 \\
\hline Protein AMBP (AMBP) P02760 & Chitinase-3-like protein 1 (CHI3L1) P36222 \\
\hline Proteinase-activated receptor 1 (PAR-1) P25116 & Chitotriosidase-1 (CHIT1) Q13231 \\
\hline Protein-glutamine gamma-glutamyltransferase 2 (TGM2) P21980 & Collagen alpha-1(I) chain (COL1A1) P02452 \\
\hline Proto-oncogene tyrosine-protein kinase Src (SRC) P12931 & Complement component C1q receptor (CD93) Q9NPY3 \\
\hline Renin (REN) P00797 & Cystatin-B (CSTB) P04080 \\
\hline Serine protease 27 (PRSS27) Q9BQR3 & Elafin (PI3) P19957 \\
\hline Serine/threonine-protein kinase 4 (STK4) Q13043 & Ephrin type-B receptor 4 (EPHB4) P54760 \\
\hline Serpin A12 (SERPINA12) Q8IW75 & Epidermal growth factor receptor (EGFR) P00533 \\
\hline SLAM family member 5 (CD84) Q9UIB8 & Epithelial cell adhesion molecule (Ep-CAM) P16422 \\
\hline SLAM family member 7 (SLAMF7) Q9NQ25 & E-selectin (SELE) P16581 \\
\hline Sortilin (SORT1) Q99523 & Fatty acid-binding protein, adipocyte (FABP4) P15090 \\
\hline Spondin-2 (SPON2) Q9BUD6 & Galectin-3 (Gal-3) P17931 \\
\hline Stem cell factor (SCF) P21583 & Galectin-4 (Gal-4) P56470 \\
\hline Tissue factor (TF) P13726 & Integrin beta-2 (ITGB2) P05107 \\
\hline TNF-related apoptosis-inducing ligand receptor 2 (TRAIL-R2) O14763 & Intercellular adhesion molecule 2 (ICAM-2) P13598 \\
\hline $\begin{array}{l}\text { Tumor necrosis factor receptor superfamily member 10A (TNFRSF10A) } \\
\text { O00220 }\end{array}$ & Interleukin-1 receptor type 1 (IL-1RT1) P14778 \\
\hline $\begin{array}{l}\text { Tumor necrosis factor receptor superfamily member 11A (TNFRSF11A) } \\
\text { Q9Y6Q6 }\end{array}$ & Interleukin-1 receptor type 2 (IL-1RT2) P27930 \\
\hline $\begin{array}{l}\text { Tumor necrosis factor receptor superfamily member 13B (TNFRSF13B) } \\
\text { O14836 }\end{array}$ & Interleukin-2 receptor subunit alpha (IL2-RA) P01589 \\
\hline Tyrosine-protein kinase Mer (MERTK) Q12866 & Interleukin-6 receptor subunit alpha (IL-6RA) P08887 \\
\hline Vascular endothelial growth factor D (VEGFD) O43915 & Interleukin-17 receptor A (IL-17RA) Q96F46 \\
\hline $\begin{array}{l}\text { V-set and immunoglobulin domain-containing protein } 2 \text { (VSIG2) } \\
\text { Q96IQ7 }\end{array}$ & Interleukin-18-binding protein (IL-18BP) O95998 \\
\hline Cardiovascular III panel & Junctional adhesion molecule A (JAM-A) Q9Y624 \\
\hline Aminopeptidase N (AP-N) P15144 & Kallikrein-6 (KLK6) Q92876 \\
\hline Azurocidin (AZU1 P20160 & Low-density lipoprotein receptor (LDL receptor) P01130 \\
\hline Bleomycin hydrolase (BLM hydrolase) Q13867 & Lymphotoxin-beta receptor (LTBR) P36941 \\
\hline Cadherin-5 (CDH5) P33151 & Matrix extracellular phosphoglycoprotein (MEPE) Q9NQ76 \\
\hline Carboxypeptidase A1 (CPA1) P15085 & Matrix metalloproteinase-2 (MMP-2) P08253 \\
\hline Carboxypeptidase B (CPB1) P15086 & Matrix metalloproteinase-3 (MMP-3) P08254 \\
\hline
\end{tabular}




\begin{tabular}{|c|c|}
\hline Matrix metalloproteinase-9 (MMP-9) P14780 & von Willebrand factor (vWF) P04275 \\
\hline \multicolumn{2}{|l|}{ Metalloproteinase inhibitor 4 (TIMP4) Q99727 } \\
\hline Monocyte chemotactic protein 1 (MCP-1) P13500 & Inflammation panel \\
\hline Myeloperoxidase (MPO) P05164 & Artemin (ARTN) Q5T4W7 \\
\hline Myoglobin (MB) P02144 & Axin-1 (AXIN1) O15169 \\
\hline Osteopontin (OPN) P10451 & C-C motif chemokine 3 (CCL3) P10147 \\
\hline Osteoprotegerin (OPG) O00300 & C-C motif chemokine 4 (CCL4) P13236 \\
\hline Paraoxonase (PON3) Q15166 & C-C motif chemokine 19 (CCL19) Q99731 \\
\hline Peptidoglycan recognition protein 1 (PGLYRP1) O75594 & C-C motif chemokine 20 (CCL20) P78556 \\
\hline Platelet-derived growth factor subunit A (PDGF subunit A) P04085 & CD40L receptor $(\mathrm{CD} 40) \mathrm{P} 25942$ \\
\hline Proprotein convertase subtilisin/kexin type 9 (PCSK9) Q8NBP7 & CUB domain-containing protein 1 (CDCP1) Q9H5V8 \\
\hline Protein delta homolog 1 (DLK-1) P80370 & C-X-C motif chemokine 1 (CXCL1) P09341 \\
\hline P-selectin (SELP) P16109 & C-X-C motif chemokine 5 (CXCL5) P42830 \\
\hline Pulmonary surfactant-associated protein D (PSP-D) P35247 & C-X-C motif chemokine 6 (CXCL6) P80162 \\
\hline Resistin (RETN) Q9HD89 & C-X-C motif chemokine 9 (CXCL9) Q07325 \\
\hline Retinoic acid receptor responder protein 2 (RARRES2) Q99969 & C-X-C motif chemokine 10 (CXCL10) P02778 \\
\hline Scavenger receptor cysteine-rich type 1 protein M130 (CD163) Q86VB7 & C-X-C motif chemokine 11 (CXCL11) O14625 \\
\hline Tissue-type plasminogen activator (t-PA) P00750 & Fibroblast growth factor 23 (FGF-23) Q9GZV9 \\
\hline Transferrin receptor protein 1 (TR) P02786 & Fibroblast growth factor 5 (FGF-5) Q8NF90 \\
\hline Trefoil factor 3 (TFF3) Q07654 & Fibroblast growth factor 19 (FGF-19) O95750 \\
\hline Trem-like transcript 2 protein (TLT-2) Q5T2D2 & Fms-related tyrosine kinase 3 ligand (Flt3L) P49771 \\
\hline $\begin{array}{l}\text { Tumor necrosis factor ligand superfamily member 13B (TNFSF13B) } \\
\text { Q9Y275 }\end{array}$ & Fractalkine (CX3CL1) P78423 \\
\hline Tumor necrosis factor receptor 1 (TNF-R1) P19438 & Glial cell line-derived neurotrophic factor (GDNF) P39905 \\
\hline Tumor necrosis factor receptor 2 (TNF-R2) P20333 & Hepatocyte growth factor (HGF) P14210 \\
\hline Tumor necrosis factor receptor superfamily member 6 (FAS) P25445 & Interferon gamma (IFN-gamma) P01579 \\
\hline $\begin{array}{l}\text { Tumor necrosis factor receptor superfamily member 10C (TNFRSF10C) } \\
\text { O14798 }\end{array}$ & Interleukin-1 alpha (IL-1 alpha) P01583 \\
\hline $\begin{array}{l}\text { Tumor necrosis factor receptor superfamily member } 14 \text { (TNFRSF14) } \\
\text { Q92956 }\end{array}$ & Interleukin-2 (IL-2) P60568 \\
\hline Tyrosine-protein kinase receptor UFO (AXL) P30530 & Interleukin-2 receptor subunit beta (IL-2RB) P14784 \\
\hline $\begin{array}{l}\text { Tyrosine-protein phosphatase non-receptor type substrate 1 (SHPS-1) } \\
\text { P78324 }\end{array}$ & Interleukin-4 (IL-4) P05112 \\
\hline Urokinase plasminogen activator surface receptor (U-PAR) Q03405 & Interleukin-5 (IL5) P05113 \\
\hline Urokinase-type plasminogen activator (uPA) P00749 & Interleukin-6 (IL6) P05231 \\
\hline
\end{tabular}




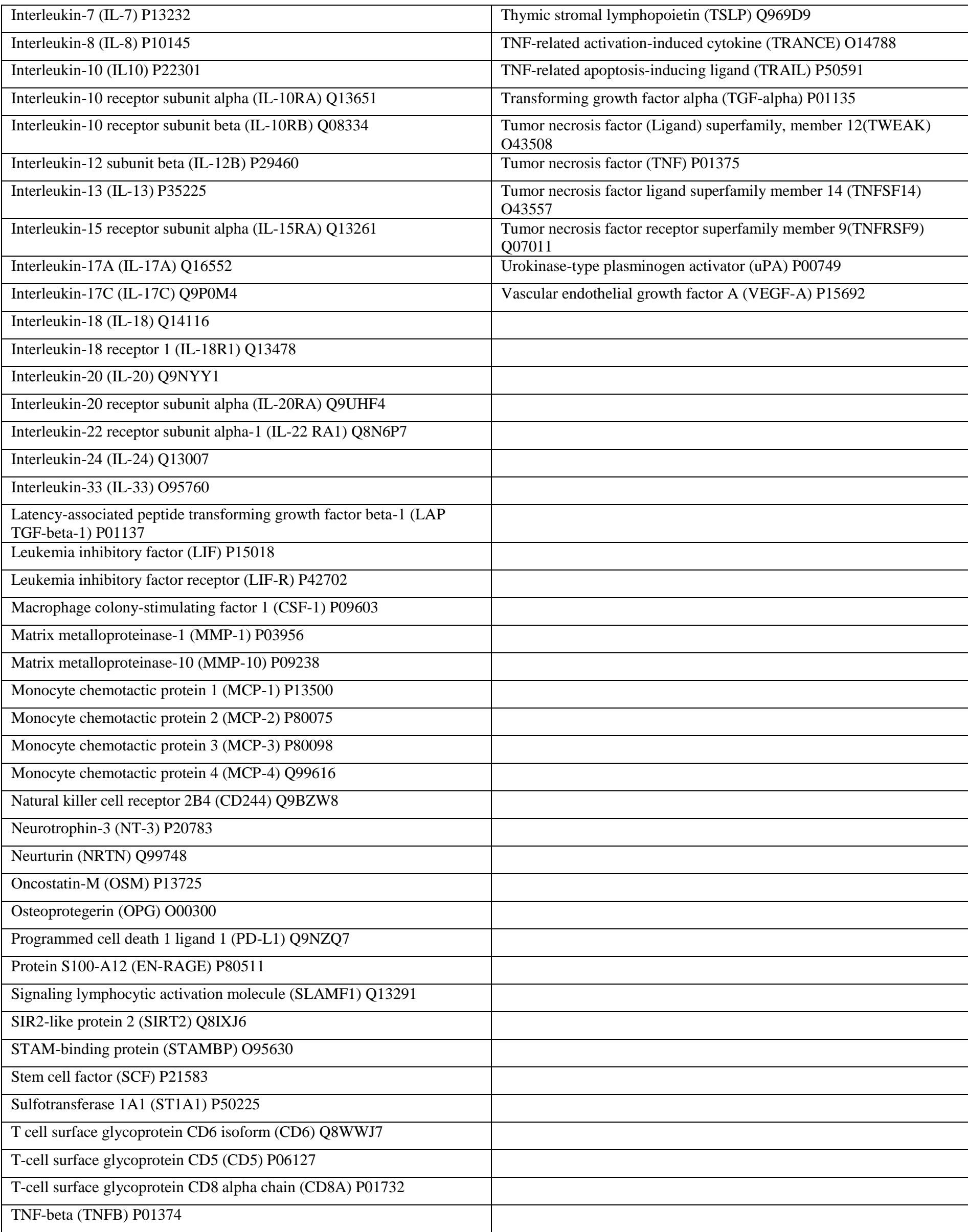




\begin{tabular}{|l|}
\hline Sex \\
\hline Age \\
\hline Recently decompensated (<60 days) HF \\
\hline Smoking status \\
\hline Alcohol consumption \\
\hline Body mass index (BMI) \\
\hline Systolic blood pressure (SBP) \\
\hline Diastolic blood pressure (DBP) \\
\hline Pulmonary rales \\
\hline New York Heart Association (NYHA) \\
\hline Peripheral edema \\
\hline Jugular Venous Distension \\
\hline Fatigue on exertion \\
\hline Hepatomegaly \\
\hline Heart rate \\
\hline Previous HF hospitalization \\
\hline Atrial fibrillation \\
\hline Hypertension \\
\hline Diabetes Mellitus \\
\hline Coronary Artery Disease (CAD) \\
\hline Stroke or Transient Ischemic Attack \\
\hline Peripheral arterial disease \\
\hline Chronic obstructive pulmonary disease \\
\hline Total cholesterol \\
\hline Anemia (defined as hemoglobin $<12$ g/dL in women and $<13$ g/dL \\
following WHO definition) \\
\hline Estimated glomerular filtration rate (MDRD) \\
\hline ACE inhibitor or angiotensin receptor blocker \\
\hline Betablocker \\
\hline Loop diuretic \\
\hline Thiazide diuretic \\
\hline Mineralocorticoid receptor antagonist \\
\hline Oral anticoagulant \\
\hline Insulin \\
\hline Statin \\
\hline Left ventricular ejection fraction (LV \\
\hline LV end-diastolic index (LVEDVi) \\
\hline LV end-systolic volume index (LVESVi), \\
\hline left atrial volume index (LAVi) \\
\hline tricuspid annular plane systolic excursion (TAPSE) \\
\hline ratio of early mitral inflow E to annular velocity e' (E/e')) \\
\hline Excluded variables ( $\geq 20 \%$ missing) \\
\hline pulmonary artery systolic pressure (PASP) \\
\hline Ratio of the early (E) to late (A) ventricular filling velocities (E/A) \\
\hline Waist circumference \\
\hline Sodium \\
\hline Potassium \\
\hline CRP \\
\hline
\end{tabular}




\section{Supplemental table 4}

\section{Average measure of biomarkers according to respective clusters}

\begin{tabular}{|l|c|c|l|}
\hline & $\begin{array}{c}\text { Cluster 1 } \\
(\mathbf{N}=\mathbf{2 2 9})\end{array}$ & $\begin{array}{c}\text { Cluster 2 } \\
(\mathbf{N = 1 6 3})\end{array}$ & p-value \\
\hline TIE2 & $7.1 \pm 0.3$ & $7.3 \pm 0.2$ & $<0.001$ \\
\hline ENTPD2 & $0.0 \pm 0.2$ & $0.1 \pm 0.3$ & $<0.001$ \\
\hline CCL11 & $7.5 \pm 0.4$ & $7.8 \pm 0.4$ & $<0.001$ \\
\hline TNFSF13B & $5.7 \pm 0.4$ & $6.0 \pm 0.5$ & $<0.001$ \\
\hline PDGFC & $2.2 \pm 0.4$ & $2.3 \pm 0.3$ & $<0.001$ \\
\hline SELL & $7.5 \pm 0.4$ & $7.6 \pm 0.4$ & 0.006 \\
\hline PCSK9 & $1.8 \pm 0.4$ & $2.0 \pm 0.4$ & $<0.001$ \\
\hline TWEAK & $9.0 \pm 0.5$ & $9.1 \pm 0.4$ & 0.002 \\
\hline NOS3 & $1.3 \pm 0.6$ & $1.7 \pm 0.6$ & $<0.001$ \\
\hline GNLY & $0.5 \pm 0.4$ & $0.7 \pm 0.5$ & $<0.001$ \\
\hline SELE & $12.1 \pm 0.6$ & $12.3 \pm 0.7$ & $<0.001$ \\
\hline SERPINA9 & $2.4 \pm 0.6$ & $2.8 \pm 0.8$ & $<0.001$ \\
\hline AZU1 & $3.4 \pm 0.8$ & $3.8 \pm 1.2$ & $<0.001$ \\
\hline SRC & $6.5 \pm 1.2$ & $6.9 \pm 1.0$ & 0.001 \\
\hline ADGRG1 & $1.4 \pm 1.0$ & $2.2 \pm 1.3$ & $<0.001$ \\
\hline FGF_21 & $5.7 \pm 1.2$ & $6.6 \pm 1.5$ & $<0.001$ \\
\hline GH & $7.6 \pm 1.7$ & $8.5 \pm 1.6$ & $<0.001$ \\
\hline
\end{tabular}

Legend: TIE2, angiopoietin-1 receptor; ENTPD2, ectonucleoside triphosphate diphosphohydrolase 2; CCL11, eotaxin; TNFSF13B, tumor necrosis factor ligand superfamily member 13B; PDGFC, platelet-derived growth factor C; SELL, Lselectin; PCSK9, proprotein convertase subtilisin/kexin type 9; TWEAK, tumor necrosis factor (Ligand) superfamily, member 12; NOS3, nitric oxide synthase; GNLY, granulysin; SELE, E-selectine; SERPINA9, serpin A9; AZU1, azurocidin; SRC, Proto-oncogene tyrosine-protein kinase Src; ADGRG1, adhesion G-protein coupled receptor G1; FGF_21_1, fibroblast growth factor 21; GH, growth hormone.

Biomarker results depict log2-normalized protein expression (NPX) data and an increase of 1 NPX confers therefore a doubling in concentration of the specific biomarker. For every biomarker the mean and standard deviation are listed. 

at 1 year in MEDIA-DHF

\begin{tabular}{|l|c|c|c|c|}
\hline & \multicolumn{2}{|c|}{ UNIVARIATE ANALYSES } & \multicolumn{2}{c|}{ MULTIVARIATE ANALYSES } \\
\hline & HR $(95 \%$ CI $)$ & p-value & HR (95\% CI) & p-value \\
\hline Pulmonary rales & $2.28(1.34-3.86)$ & 0.002 & $2.14(1.25-3.68)$ & 0.006 \\
\hline History of CAD & $1.78(1.06-2.99)$ & 0.028 & $1.96(1.15-3.42)$ & 0.013 \\
\hline Previous HF hospitalization & $1.75(1.06-2.91)$ & 0.030 & & \\
\hline eGFR < 60 mL/min/1.73m2 & $1.51(1.30-1.76)$ & $<0.001$ & & \\
\hline Anemia & $1.50(1.28-1.75)$ & $<0.001$ & & \\
\hline E/e'>9 & $3.37(2.48-4.58)$ & $<0.001$ & & 0.59 \\
\hline Age (per 10 years) & $1.00(0.76-1.31)$ & 0.99 & $0.93(0.70-1.22)$ & 0.18 \\
\hline Female sex & $1.26(0.73-2.16)$ & 0.41 & $1.48(0.83-2.63)$ & \\
\hline
\end{tabular}

The table depicts pooled estimates derived after multiple imputation in 10 datasets. Anemia is defined following the WHO criteria for anemia ( $\mathrm{Hb}<12 \mathrm{~g} / \mathrm{dl}$ in women; $\mathrm{Hb}<13$ in males).

Legend: $\mathrm{HR}$, hazard ratio; $\mathrm{CI}$, confidence interval; $\mathrm{CAD}$, coronary artery disease; $\mathrm{HF}$, heart failure; eGFR, estimated glomerular filtration rate; $\mathrm{E} / \mathrm{E}$ ', the ratio of early mitral inflow $\mathrm{E}$ to $\mathrm{e}^{\prime}$ 


\begin{tabular}{|c|c|c|c|c|c|c|c|c|c|c|}
\hline & & & \multicolumn{8}{|c|}{ Additional adjusted variables on top of clinical + cluster model } \\
\hline & Clinical & Clinical + cluster & + prev HF hosp & + anemia & + SBP & NYHA 3/4 & DM 2 & ACE/ARB & BB & MRA \\
\hline & HR (95\% CI) & $\mathrm{HR}(95 \% \mathrm{CI})$ & HR $(95 \% \mathrm{CI})$ & HR (95\% CI) & HR $(95 \% \mathrm{CI})$ & $\mathrm{HR}(95 \% \mathrm{CI})$ & HR (95\% CI) & HR $(95 \% \mathrm{CI})$ & $\mathrm{HR}(95 \% \mathrm{CI})$ & HR $(95 \% \mathrm{CI})$ \\
\hline $\begin{array}{l}\text { Pulmonary } \\
\text { rales }\end{array}$ & $\begin{array}{c}2.14 \\
(1.25-3.68) \\
p=0.006\end{array}$ & $\begin{array}{c}2.17 \\
(1.26-3.72) \\
P=0.005\end{array}$ & $\begin{array}{c}2.14 \\
(1.24-3.67) \\
P=0.006\end{array}$ & $\begin{array}{c}2.85 \\
(1.61-5.01) \\
\mathrm{P}<0.001\end{array}$ & $\begin{array}{c}2.24 \\
(1.29-3.88) \\
\mathrm{P}=0.004\end{array}$ & $\begin{array}{c}2.19 \\
(1.27-3.78) \\
P=0.005\end{array}$ & $\begin{array}{c}2.12 \\
(1.23-3.66) \\
P=0.007\end{array}$ & $\begin{array}{c}2.19 \\
(1.27-3.76) \\
P=0.005\end{array}$ & $\begin{array}{c}2.10 \\
(1.22-3.63) \\
\mathrm{P}=0.008\end{array}$ & $\begin{array}{c}2.17 \\
(1.27-3.73) \\
P=0.01\end{array}$ \\
\hline $\begin{array}{l}\text { History of } \\
\text { CAD }\end{array}$ & $\begin{array}{c}1.96 \\
(1.15-3.42) \\
p=0.013\end{array}$ & $\begin{array}{c}2.01 \\
(1.26-3.46) \\
\mathrm{P}=0.012\end{array}$ & $\begin{array}{c}1.88 \\
(1.09-3.26) \\
\mathrm{P}=0.024\end{array}$ & $\begin{array}{c}1.84 \\
(1.02-3.31) \\
\mathrm{P}=0.04\end{array}$ & $\begin{array}{c}1.83 \\
(1.05-3.20) \\
\mathrm{P}=0.034\end{array}$ & $\begin{array}{c}2.05 \\
(1.18-3.56) \\
\mathrm{P}=0.011\end{array}$ & $\begin{array}{c}1.98 \\
(1.15-3.42) \\
\mathrm{P}=0.014\end{array}$ & $\begin{array}{c}2.02 \\
(1.17-3.49) \\
P=0.01\end{array}$ & $\begin{array}{c}1.95 \\
(1.12-3.38) \\
\mathrm{P}=0.02\end{array}$ & $\begin{array}{c}2.02 \\
(1.17-3.49) \\
P=0.01\end{array}$ \\
\hline $\begin{array}{l}\text { Age (per } 10 \\
\text { years) }\end{array}$ & $\begin{array}{c}0.93 \\
(0.70-1.22) \\
p=0.059\end{array}$ & $\begin{array}{c}0.86 \\
(0.65-1.13) \\
P=0.27\end{array}$ & $\begin{array}{c}0.85 \\
(0.65-1.12) \\
P=0.26\end{array}$ & $\begin{array}{c}0.86 \\
(0.63-1.17) \\
P=0.34\end{array}$ & $\begin{array}{c}0.88 \\
(0.66-1.17) \\
\mathrm{P}=0.38\end{array}$ & $\begin{array}{c}0.84 \\
(0.64-1.12) \\
P=0.23\end{array}$ & $\begin{array}{c}0.87 \\
(0.66-1.16) \\
P=0.36\end{array}$ & $\begin{array}{c}0.85 \\
(0.64-1.13) \\
P=0.26\end{array}$ & $\begin{array}{c}0.87 \\
(0.65-1.15) \\
\mathrm{P}=0.33\end{array}$ & $\begin{array}{c}0.87 \\
(0.65-1.14) \\
\mathrm{P}=0.31\end{array}$ \\
\hline Female sex & $\begin{array}{c}1.48 \\
(0.83-2.63) \\
\mathrm{P}=0.018\end{array}$ & $\begin{array}{c}1.68 \\
(0.93-3.02) \\
\mathrm{P}=0.085 \\
\end{array}$ & $\begin{array}{c}1.80 \\
(0.99-3.26) \\
0.053\end{array}$ & $\begin{array}{c}1.51 \\
(0.80-2.89) \\
\mathrm{P}=0.34 \\
\end{array}$ & $\begin{array}{c}1.71 \\
(0.93-3.12) \\
\mathrm{P}=0.083\end{array}$ & $\begin{array}{c}1.65 \\
(0.91-2.98) \\
P=0.09\end{array}$ & $\begin{array}{c}1.70 \\
(0.94-3.08) \\
P=0.08\end{array}$ & $\begin{array}{c}1.69 \\
(0.94-3.04) \\
\mathrm{P}=0.08\end{array}$ & $\begin{array}{c}1.69 \\
(0.94-3.04) \\
\mathrm{P}=0.08\end{array}$ & $\begin{array}{c}1.67 \\
(0.92-3.00) \\
P=0.09\end{array}$ \\
\hline Cluster 2 & & $\begin{array}{c}1.93 \\
(1.12-1.32) \\
P=0.018 \\
\end{array}$ & $\begin{array}{c}1.81 \\
(1.05-3.13) \\
P=0.033 \\
\end{array}$ & $\begin{array}{c}1.69 \\
(0.93-3.07) \\
P=0.087 \\
\end{array}$ & $\begin{array}{c}2.04 \\
(1.17-3.57) \\
\mathbf{P}=0.012 \\
\end{array}$ & $\begin{array}{c}1.84 \\
(1.06-3.19) \\
P=0.029 \\
\end{array}$ & $\begin{array}{c}1.90 \\
(1.10-3.27) \\
P=0.021 \\
\end{array}$ & $\begin{array}{c}1.90 \\
(1.10-3.28) \\
P=0.02\end{array}$ & $\begin{array}{c}1.86 \\
(1.08-3.23) \\
P=0.03\end{array}$ & $\begin{array}{c}1.99 \\
(1.15-3.42) \\
P=0.01\end{array}$ \\
\hline $\begin{array}{l}\text { Previous HF } \\
\text { hosp }\end{array}$ & & & $\begin{array}{c}1.53 \\
(0.89-2.65) \\
\mathrm{P}=0.13)\end{array}$ & & & & & & & \\
\hline Anemia & & & & $\begin{array}{c}1.21 \\
(0.67-2.16) \\
0.53\end{array}$ & & & & & & \\
\hline SBP & & & & & $\begin{array}{c}0.99 \\
(0.98-1.01) \\
\mathrm{P}=0.83\end{array}$ & & & & & \\
\hline NYHA $3 / 4$ & & & & & & $\begin{array}{c}1.23 \\
(0.65-2.31) \\
\mathrm{P}=0.53\end{array}$ & & & & \\
\hline DM type 2 & & & & & & & $\begin{array}{c}1.21 \\
(0.71-2.08) \\
\mathrm{P}=0.49\end{array}$ & & & \\
\hline ACE/ARB & & & & & & & & $\begin{array}{c}0.84 \\
(0.45-1.58) \\
\mathrm{P}=0.59\end{array}$ & & \\
\hline BB & & & & & & & & & $\begin{array}{c}1.29 \\
(0.65-2.56) \\
\mathrm{P}=0.47 \\
\end{array}$ & \\
\hline MRA & & & & & & & & & & $\begin{array}{c}0.60 \\
(0.24-1.52) \\
P=0.28\end{array}$ \\
\hline
\end{tabular}




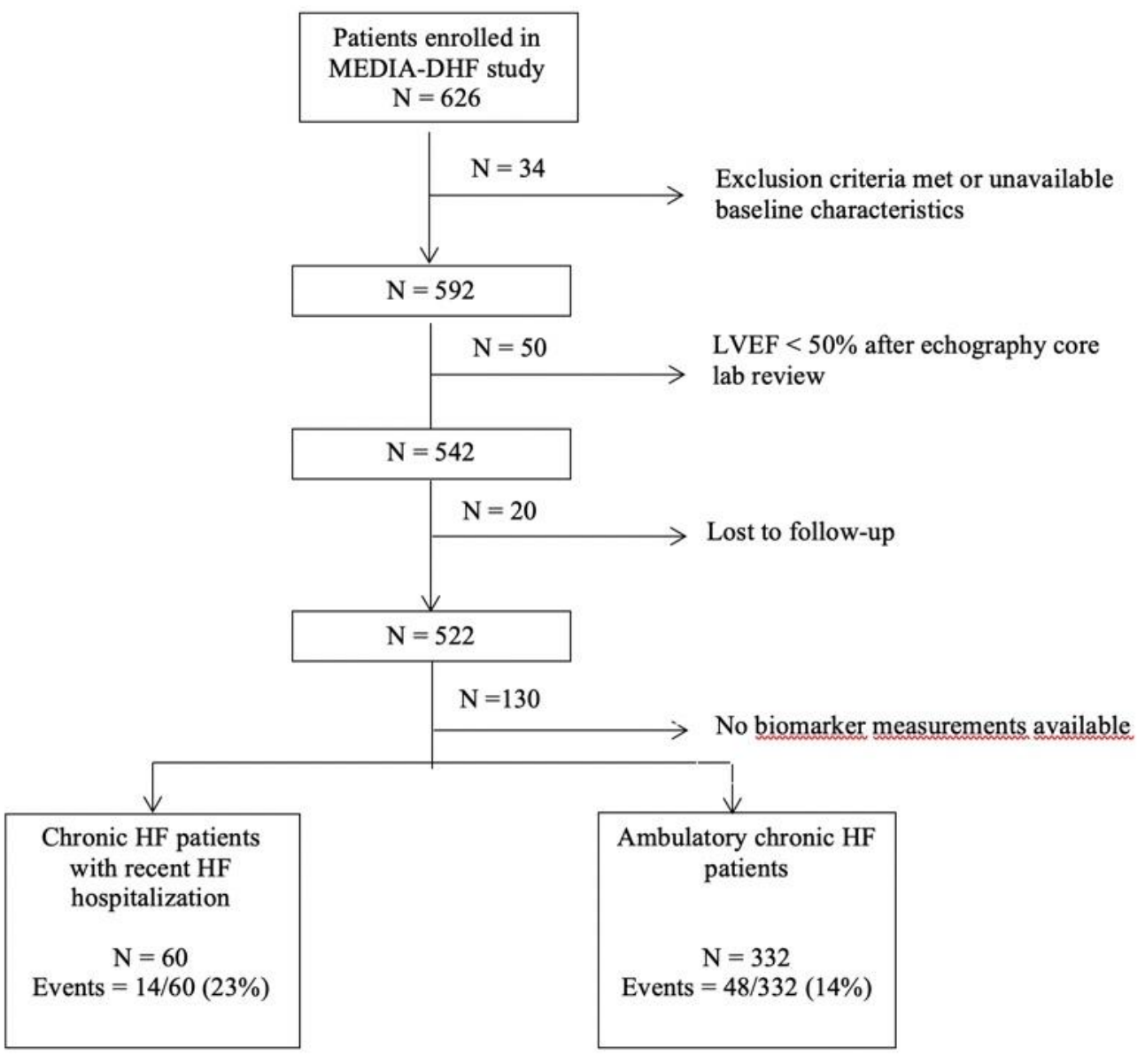




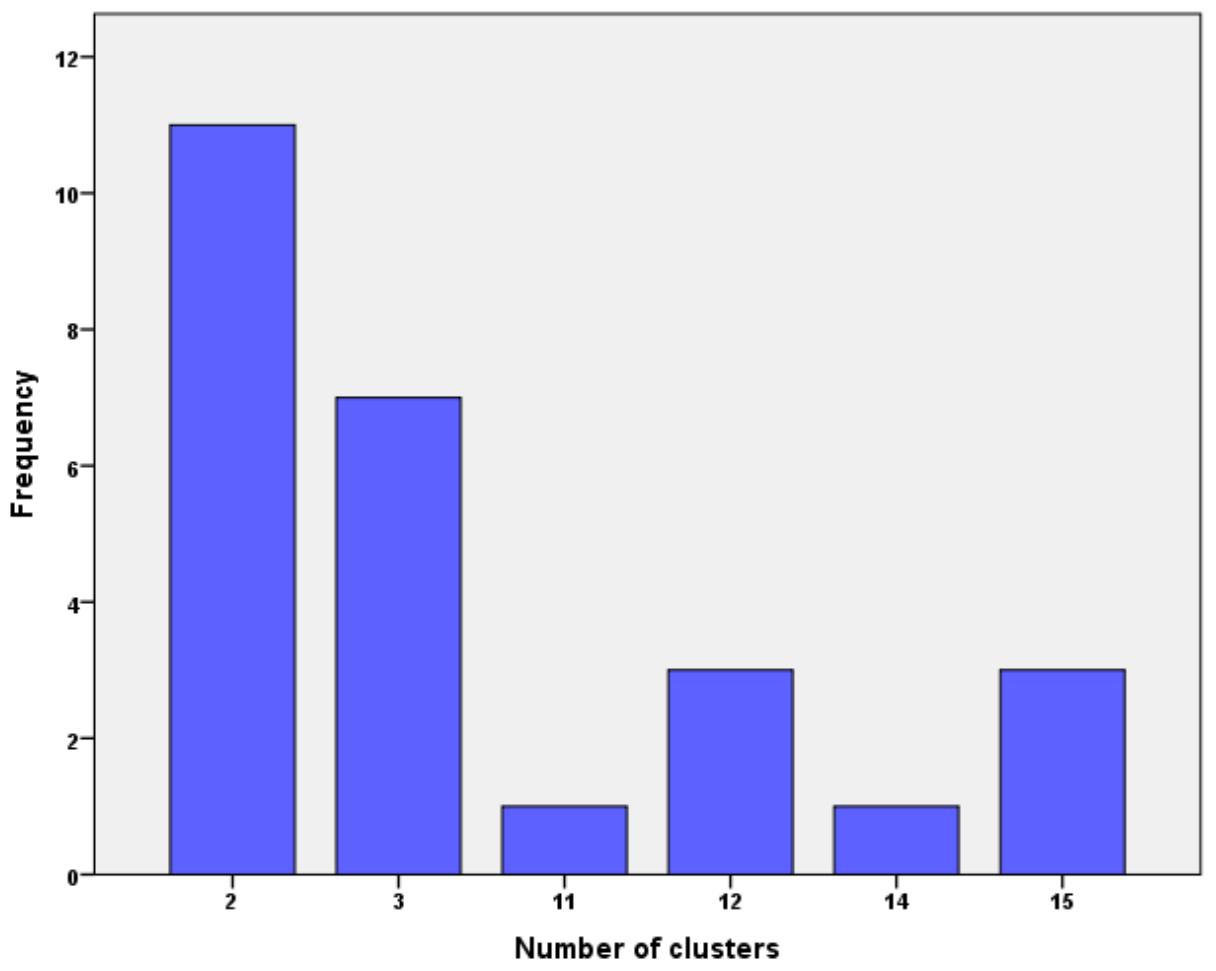

The optimal number of clusters determined by the $N b$ Clust package in $\mathrm{R}$ was 2 . This package uses a total of 30 indices for determining the most optimal number of clusters from the results obtained by varying combinations of number of clusters, distance measures and clustering methods 
